\title{
Relative sea-level development and isostasy along the NE German Baltic Sea coast during the past 9 ka.
}

\author{
Reinhard Lampe, Elisabeth Endtmann, Wolfgang Janke, Hinrich Meyer
}

Abstract:

\begin{abstract}
Recent gauge data from coastal NE-Germany (Baltic Sea) suggest that the eustatic component of the observed sea-level record is superimposed by a spatially different non-eustatic, predominantly glacio-isostatic component. To investigate to which amount the past sea level was influenced by these two components, we traced the sea-level history back as far as the coastal sediment sequence allowed. Three new relative sea-level curves have been established, two of them are presented here for the first time. The curves are based on numerous AMS-radiocarbon data from sea-level index points such as basal peat layers, archaeological underwater finds and from peat profiles taken in coastal mires. Although the validity of the mire samples is questionable due to possible compaction reliable results were gained by cross-checking data from different palaeo-environments against each other. The three sea-level curves established cover the period from today back to 6,000 or 7,000 BC to the present and diverge regularly with increasing age. A shoreline diagram reveals that no tectonic events disturbed the spatial movement pattern significantly. For the determination of the isostatic component the sea-level curves were compared with one from the Belgian coast (DENYs/BAETEMAN 1995), which is assumed to be tectonically and isostatically more stable and therefore shows the eustatic component only. The comparison suggests that the SW section of the German Baltic coast is still slightly submerging probably due to glacial forebulge decay. While at the central section the isostatic uplift faded out a few thousand years ago, it is still going on in the northern section. Here, the maximal uplift during the past $9 \mathrm{ka}$ amounts to about $6 \mathrm{~m}$ relative to the Belgian coast.
\end{abstract}

[Relative Meeresspiegelentwicklung und Isostasie entlang der nordostdeutschen Ostseeküste während der letzten 9000 Jahre]

Kurzfassung:

Jüngere Pegeldaten aus dem nordostdeutschen Ostsee-Küstenraum legen nahe, dass die eustatische Komponente der gegenwärtigen Meeresspiegeländerung überlagert wird durch eine räumlich differenzierte nicht-eustatische, insbesondere glazialisostatisch, Komponente. Um zu untersuchen, in welchem Maße die frühere Meeresspiegelentwicklung durch diese beiden Komponenten beeinflusst wurde, wurde versucht, diese so weit zurück zu verfolgen, wie dies die Mächtigkeit der marinen Küstensedimentfolgen erlaubte.

Drei neue relative Meeresspiegelkurven wurden abgeleitet, wovon zwei hier zum ersten Mal präsentiert werden. Die Kurven basieren auf zahlreichen AMS-Radiokohlenstoff-Datierungen von Meeresspiegel-Indexpunkten wie Basistorfen, archäologischen Unterwasserfunden und Torfprofilen aus Küstenüberflutungsmooren. Obwohl der Indikationswert der Proben aus den Küstenmooren wegen deren möglicher Kompaktion fraglich ist, konnten zuverlässige Angaben durch den Abgleich von Daten aus unterschiedlichen Ablagerungsräumen gewonnen werden. Die drei abgeleiteten Meeresspiegelkurven überdecken den Zeitraum von 6000 bis 7000 v. Chr. bis zur Gegenwart und divergieren gleichmäßig mit zunehmendem Alter. Ein Uferlinienverschiebungsdiagramm zeigt, dass tektonische Ereignisse dieses räumliche Bewegungsmuster nicht signifikant beeinflusst haben.

Für die Bestimmung der isostatischen Komponente wurden die Meeresspiegelkurven verglichen mit einer von DeNYs/BAETEMAN (1995) publizierten Kurve für die belgische Küste, die als tektonisch und isostatisch stabiler gilt. Der Verlauf dieser Kurve wird daher hauptsächlich von der eustatischen Komponente bestimmt. Der Vergleich legt nahe, dass der SW-Abschnitt der deutschen Ostseeküste gegenwärtig eine leichte Submergenz aufweist, möglicherweise infolge eines sich rückbildenden, glazial bedingten Randwulstes. Im zentralen Abschnitt ist die isostatische Bewegung vor wenigen Tausend Jahren ausgeklungen, im nördlichen Abschnitt hält sie dagegen immer noch an. Hier beträgt die maximale Hebung während der letzten 9000 Jahre etwa $6 \mathrm{~m}$ relativ zur belgischen Küste.

Key words: $\quad$ Baltic Sea, NE Germany, relative sea-level, isostasy, sea-level fluctuations, coastal mires, macrofossils, radiocarbon dating

Addresses of authors: R. Lampe* ${ }^{*}$ W. Janke, H. Meyer, Institut für Geographie und Geologie, Ernst-Moritz-Arndt-Universität Greifswald, F.-L.-JahnStr. 16, D-17487 Greifswald. E-Mail: lampe@uni-greifswald.de; E. Endtmann, Naturkundliches Museum Mauritianum Altenburg, Parkstr. 1a, D-04603 Altenburg. E-Mail: endtmann@mauritianum.de; *corresponding author

\section{Introduction}

Late Quaternary sea-level history from northwestern Europe reflects the temporally and spatially varying influence of eustatic, isostatic, tectonic and geoidal components, and, to a minor extent of local factors such as sediment compaction, halokinetics and hydrographic fluctuations. The many combinations of these factors within a rather limited area make Northwest Europe an intensively studied natural sealevel lab (Mörner 1980). This paper focuses on the Baltic Sea coast of NE Germany (Mecklenburg-Vorpommern) within a time frame from 7,000 BC until today.
Since the last Scandinavian Ice shield started to melt at about 18,000 BC and vanished from the present southern Baltic coast at about 13,000 BC, the Baltic Sea Basin was, except for some short periods, isolated from the ocean until the Mid-Holocene. Its water level was determined by highly fluctuating lakes, which are called the Baltic Ice Lake (-15 to $-40 \mathrm{~m}$ msl; 13,500 to $10,200 \mathrm{BC})$, the Yoldia Sea ( $-40 \mathrm{~m}$ msl; 10,200 to $8,900 \mathrm{BC}$ ) and the Ancylus Lake (-40 to $-20 \mathrm{~m}$ msl; 8,900 to 7,200 BC; BJÖRK 1995; LeMKE 1998; LAMBECK 1999; LAMPE 2005a). Only after about 7,200 BC was the basin permanently linked to the ocean, when the North Sea water table rose above the sills in the Great and the Little Belt (today 
$-24 \mathrm{~m}$ and $-20 \mathrm{~m} \mathrm{msl}$, respectively). The resulting sea-level (sl) rise in the Baltic Basin is called the Littorina transgression. The course of the Littorina rise was different in the riparian countries around the Baltic. The relative sea-level (rsl) curves from Sweden, Finland and parts of Denmark and Estonia predominantly reflect the postglacial uplift of Fennoscandia (Christensen 1995, Christensen ET AL. 1997; HYväRINEN 2000; SAARSE ET AL. 2000;) with land uplift occurring faster than the water table rise. Along the southern shore more stable areas predominate, such as in Lithuania (Kabailiene 1999), Poland (TomczaK 1995; Rosa 1997; UŚcINOWICZ 2006), Germany (Köster 1961; DupHORN 1979; Klug 1980; Kliewe/JANKe 1982; KolP 1982; WinN ET AL. 1986; SCHUMACHER/BAYERL 1999; LAMPE 2005a) and southern Denmark (Christensen 1995; BenNike/JENSEN 1998; WINN ET AL. 1998; BJORNSEN ET AL. 2008), where the water table rise rather caused a drowning of the landscape.

A comparison of the many rsl curves from these latter countries shows that they are similar to each other in the rapid rsl ascent before 5,000 $\mathrm{BC}$. The most important differences in the curves pertain to the absolute position of sl reached at this time and to the subsequent period between 5,000 and $0 \mathrm{BC}$, during which the curves differ in the temporal order of sl highstands and the magnitude of relative variations overprinted on the main trend of sl rise. Only during the last 2,000 years do the curves become more similar again. Additional differences arise when the rsl curves from the southern Baltic are compared with curves from the neighbouring southern North Sea (e. g. Kiden ET AL. 2002, BEHRE 2003, VINK ET AL. 2007). Evidently, during the Mid- to Late Holocene, the Baltic curves show a remarkably higher rsl than the North Sea curves, pointing to differential crustal movement between the two areas.

Past tidal variations as a source of uncertainty in sl determinations is insignificant along the NE German Baltic Sea coast $(<0.1 \mathrm{~m})$, which makes this coastal section an ideal region to study water-level fluctuations. Also, due to the small distances between the study areas, long-term geoidal changes are assumed to be similar and may be integrated in the eustatic component. However, the wider region is located in the transition zone between the Scandinavian Shield and the Central European Subsidence Zone, where neotectonic subsidence and isostatic uplift interact. According to the results of the IGCP-project 346 (GARETSKY ET AL. 2001; LUDWIG 2001a, b), the mean long-term neotectonic subsidence rate is estimated at $0.006 \mathrm{~mm} \mathrm{a}^{-1}$ for the Wismar area and an uplift rate of $0.004 \mathrm{~mm} \mathrm{a}^{-1}$ for the Rügen area and, therefore, does not contribute significantly to the sl development in the period studied. Hydrographic variations such as slowly changing salinity in the Baltic or fluctuations in the mean air pressure field and precipitation (HÜNICKE 2008) might also supplement to water level fluctuations in a range of one or two decimetres. Some halokinetic movements might be possible in the western part of the coastal section investigated, where Permian salt layers and pillows occur in the deeper subsoil. Repeated precision levellings demonstrate that the movement tendencies can oscillate at least on a decadal scale, with changes in movement rate concentrated around faults (ELLENBERG 1988). However, for all these components it must be recognized that, in comparison to the inherent uncertainty related to water level determina- tion based on geological methods, their contribution cannot be reliably distinguished from the main course of water level change and must therefore be neglected as separate terms. The main relative water-level development in the study area, therefore, is determined by the interplay of eustatic and isostatic components, where the latter are the results of ice or water loading or unloading due to the growth and decay of the Pleistocene ice sheets or of water level variations, respectively. Other factors as mentioned above may have local importance but will not be considered explicitly in the following paper. Their contribution is, however, considered in the vertical error of sl index point.

\section{Geographic setting}

Mecklenburg-Vorpommern's 354-km long outer (Baltic Sea) coast (fig. 1) consists of bluff sections composed of Pleistocene outwash and till, interspersed with low uplands, barriers, spits and accreting forelands composed of Holocene sand and, to a very minor extent, gravel. The sea coast provides shelter to a longer shoreline consisting of inner bays or lagoons (locally called 'bodden'). The low-lying coastal segments owe their existence to sediment supplied alongshore from eroding bluffs, which are less mobile and are believed to act as headlands (hinge points) that help stabilize adjacent shores. Approximately $70 \%$ of this Baltic Sea coast section is presently eroding at an average rate of $0.34 \mathrm{~m} \mathrm{a}^{-1}$ (MINISTERIUM FÜR BAU, LANDESENTWICKLUNG UND UMWELT 1994).

After the postglacial ocean water level had risen to the land surface altitude in the Danish Belts, the Baltic Basin became connected to the North Sea. During the subsequent Littorina transgression the landscapes off the present coast drowned. The first invasion of salt water into the Baltic Basin occurred through the Great Belt at around 7,200 BC (WINN ET AL. 1998, JENSEN ET AL. 1997, 2005, BenNiKe ET AL. 2004, RöSSLER 2006). During this early transgression phase, sl rise occurred rapidly with an ascent of more than $10 \mathrm{~mm}$ $\mathrm{a}^{-1}$ but slowed down at a later stage. Earlier investigations have shown that on Rügen the sl reached a position of $-5 \mathrm{~m}$ msl by ca. $6,000 \mathrm{BC}$ and a level between -1 to $-0.5 \mathrm{~m} \mathrm{msl}$ at ca. 4,500 BC (KLIEWE/JANKE 1982). This period during which the rate of sl rise decreased significantly coincides with the period during which the main coastal sediment wedge accumulated between the Pleistocene headlands, thereby isolating lagoons from the Baltic. During the subsequent several thousand years sl varied only slightly, and shoreline evolution was characterised mainly by progradation and dune belt development.

Recent rsl movement along the Baltic coast has been investigated using repeated precision levellings and long-term mareograph records (MoNTAG 1967, BANKwitz 1971, LieBSCH 1997, Dietrich/LieBSCH 2000). The movement pattern constraint from the latter is shown in fig. 1 and points to shoreline tilting, with a relatively lower sl rise on Rügen than at Wismar. The average eustatic rise during the past century is estimated at 1 to $1.2 \mathrm{~mm} \mathrm{a}^{-1}$ (LAMBECK ET AL. 1998, DiETRICH/LIEBSCH 2000, STIGGE 2003). It corresponds with the relative rise between Fischland (area B in fig. 1) and the coastal section west of Warnemünde and suggests that slight but increasing crustal uplift occurs from there towards Rügen, whereas subsidence occurs towards Wismar. This conclusion 


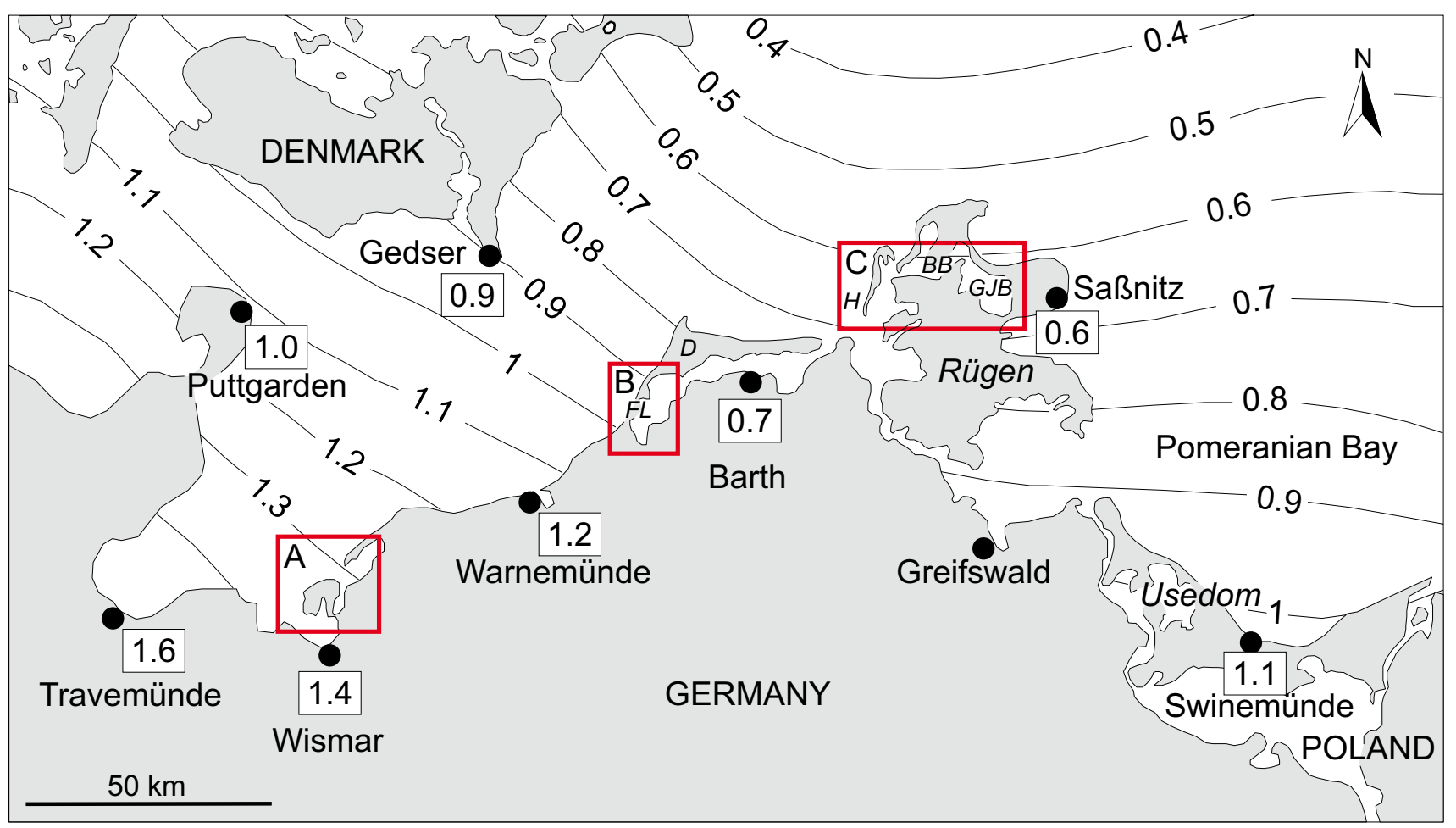

Fig. 1: Study areas Wismar Bay (A), Fischland (B) and N-Rügen/Hiddensee (C), and current rsl rise [mm a-1] at different tide gauge stations in the southern Baltic Sea (after Dietrich/LIEBSCH 2000). GJB - Großer Jasmunder Bodden, BB - Breeger Bodden, D - Darss, FL - Fischland, H - Hiddensee.

Abb. 1: Untersuchungsgebiete Wismar Bucht (A), Fischland (B) und N-Rügen/Hiddensee (C) sowie gegenwärtiger relativer Meeresspiegelanstieg (mm a-1) an Pegelstationen der südlichen Ostsee (nach DIETRICH/LIEBSCH 2000). GfB - Großer Fasmunder Bodden, BB - Breeger Bodden, D - Darss, FL - Fischland, $H$ - Hiddensee.

was already drawn by KolP (1982) and EKMAN (1996), who marked the $-1 \mathrm{~mm} \mathrm{a}^{-1}$ isobase as the isoline where glacioisostatic uplift fades out.

\section{Data aquisition}

Sl curves deduced from regionally distributed data might be flawed by differential crustal motions. To avoid this source of error, KIDEN ET AL. (2002) recommend sampling areas no larger than $30 \mathrm{~km}$ across to guarantee that differences in crustal movement within the area are negligible when comparing rates of sl rise. For this investigation, new sl data from two study areas (Fischland and North Rügen/Hiddensee, see fig. 1) were used which are located along the gradient of recent rsl change (fig. 1) and measure 30 and $40 \mathrm{~km}$ across, respectively. The mareograph records from Barth and Sassnitz, which represent the rsl rise in these two study areas, show a secular ascent of $1.0 \mathrm{~mm} \mathrm{a}^{-1}$ and $0.6 \mathrm{~mm} \mathrm{a}^{-1}$, respectively (DieTrich/LieBSCH 2000). Published data from a more southwesterly area (Wismar) were also used (LAMPE ET AL. 2005); here, mareograph records show a secular sl ascent of $1.3 \mathrm{~mm} \mathrm{a}^{-1}$ (fig. 1).

One of the basic assumptions of many sl studies is that during sl and thus local (ground) water table rise, peat growth is initiated in a near-coastal belt, the width of which depending on the inclination of the relief. In areas under tidal influence, this 'local water table' corresponds to the local mean high water level, and where no tides exist it represents the mean local (sea/river-) water level. If inclination is sufficiently steep and/or sl rise fast enough that peat growth cannot keep pace, the peat layer will be inundated and bur- ied by marine sediments. During the transgression the top of the peat layer can be eroded and, therefore, the exact time that the sea reached this height position can hardly be determined. The age data can only be used to define an upper limit for the sl position (VAn DE Plassche/Roep 1989). These 'basal peats' ('Basistorfe') provide data most frequently used for reconstructions of sl history (LANGE/MENKE 1967). However, if sl rise occurs slowly, no basal peat will develop but rather fenlands in which peat growth keeps up with water table rise. Age-height relations constrained from such dated fenland samples are generally affected by (auto-)compaction (Allen 1999).

In the predominantly siliciclastic coastal deposits along the southern Baltic coast, the problem of finding suitable dating material is critical in some aspects. In the sea area between Darss and Hiddensee, in the Pomeranian Bight and under the adjacent barriers, widespread Late Glacial basin deposits exist in depths of 8-12 $\mathrm{m}$ below msl. This restricts the delineation of the sl rise to that depth (respective to a certain age). Basal peats found further offshore, in turn, would not fulfil the condition that they should belong to the area represented by a local curve. Furthermore, peat may develop well above msl due to small variations in the Pleistocene topography and local groundwater control, and these are no basal peats sensu stricto. Diatom or macrofossil analyses are adequate tools to prove marine influence at the top of a basal peat, but because diatoms may penetrate into deeper layers and macrofossils might be reworked and redeposited, the reconstruction of the depositional environment has to be taken with caution. Basal peats do not generally occur between -4 and $-1 \mathrm{~m}$ msl due to the slow rise of sl during the Subboreal 
and Early Subatlantic. Finally, intercalated peats are absent in the clastic deposits and the dense data set required for a reliable sl curve thus cannot be established in a limited area. Therefore, to avoid the use of data from areas too large to be isostatically affected to the same extent, we have used not only data from basal peats but also from fenland Phragmites/sedge peat profiles from near-coastal valley sections inundated during the transgression. This is based on the assumption that peat growth was mainly controlled by the sl and only insignificantly influenced by groundwater flow from adjacent higher morainic areas. To evaluate sl control and problematic but unknown (auto-)compaction, the investigated profiles were carefully analysed for their palaeoenvironmental and indicative significance and especially for the intensity of marine influence using floral macro-remains (ENDTMANN 2005, 2006; LAMPE ET AL. 2005; MANDELKow ET AL. 2005, for standard preparation and determination methods see Endtmann 2006). The typical Phragmites peat found in undrained coastal mires has a very low density of about $0.13 \mathrm{~g} \mathrm{~cm}^{-3}$, the density of silty peat generally found at the top of the profiles amounts to $0.25-0.4 \mathrm{~g} \mathrm{~cm}^{-3}$. Because the mire does not grow more than about 20 to $30 \mathrm{~cm}$ above msl the effective sediment weight which can cause compaction is very low. To detect possible compacted horizons water content and dry bulk density were measured every 10 $\mathrm{cm}$ in the sediment profiles investigated. Finally, the data set was compared with age-height data from archaeological finds. Therefore, undetected compaction exceeding the vertical error range generally used in defining sl index points can be ruled out.

The samples from both basal peat layers and coastal mire profiles were palaeobotanically investigated and macro-remains from land plants were picked for dating. Macro-remains from non-aquatic plants were gathered each 25 to $50 \mathrm{~cm}$ for dating. In highly decomposed peat profile sections, no macro-remains were generally found. From these sections bulk samples, carefully purified from roots, were used for dating. All samples were ${ }^{14} \mathrm{C}$-AMS dated and calibrated to calendar years (BC/AD; DANZEGLOCKE ET AL. 2007). The data set was supplemented with datings from tree stumps and archaeological underwater finds. In a few cases, data from other authors, given in conv. BP or cal. BP, were considered, but calibrated to calendar years BC/AD for consistency reasons. For the construction of the sl curves, the double confidence interval of the calendar age ranges shown in tab. 1-3 was used. To determine the altitudinal difference between samples, all sample depths were related to recent msl which corresponds to German Ordnance Datum NHN. Considering the many errors in exact sample depths determination (such as linear interpolation between map contour lines, levelling errors, sediment dislocation due to the drilling process, instrumental errors of echosounders, unknown water level variations etc.) categories were build, in which the many single error components were considered. Depending on the sedimentary environment of the sample and the potential exactness of sample levelling the vertical height error margins for sl index points were determined as shown in tab. 1-3. Accordingly, the former sl position was estimated to -0.1 to $-0.5 \mathrm{~m}$ relative to the present sample position for precisely levelled samples from coastal mires, salt marshes and terrestrial excavation sites, to +0.2 to $-0.8 \mathrm{~m}$ for basal peats from boreholes, $-0.5 \mathrm{~m}$ for tree stumps from drowned forests, and to $+0.5 \mathrm{~m}$ for finds from underwater excavation sites. A more individual determination of vertical height error, related to each single sample, was not possible. Finally, the estimated age-depth ranges were used for the construction of the rsl curves and their error envelopes.

\section{Körkwitz study site [Fischland]}

Near the village of Körkwitz, a small coastal mire is located at the south-western shore of the lagoon Saaler Bodden. The mire was surveyed by 8 boreholes (fig. 2) to investigate depth and sediment distribution. The ground surface is about 10 to $30 \mathrm{~cm}$ above msl, with lower elevations close to the shoreline. The mire developed in a ca. 3.5 to $4.2 \mathrm{~m}$ deep depression, when the rising sl reached the location via the present-day lagoon east of the site. The extent of the western continuation is not known. The base of the mire consists of fluvio-limnic sand which contains freshwater diatoms. Upon the sand, carr peat developed in the deepest part of the depression, which can be traced into the lagoon for more than $500 \mathrm{~m}$ (boreholes SB5 to SB7, figs. 2 and 3). Within the lagoon carr peat is covered by brackish-marine mud accumulated since the marine inundation. In the mire, the inundation is marked by a thin clayey-sandy layer und a subsequent shift to Phragmites peat accumulation. Due to its very sheltered position, uninterrupted peat growth occurred, although it changed to salt meadow peat later on. The site was never drained artificially. Only an unfinished shipping channel (fig. 2) was built in the 1960's. It is assumed that the channel have had no drainage effect on the site investigated.

A pollen and a diatom diagram from the mire was published by LAMPE/JANKE (2004), and a macro-remains diagram was described by EndTMAnN (2006). Due to new radiocarbon data now available and to give a comprehensive overview of the results here, we present the most important parts of this diagram again. From the 9 boreholes surveyed, profile Koe-16 was selected for further investigations. Its base lies at $5.87 \mathrm{~m}$ below ground surface (bgs), which is about $-5.65 \mathrm{~m} \mathrm{msl}$. According to the results of the macroremain analysis, the sediment sequence can be divided into three zones with some subzones (fig. 4):

Zone Koe-16-1 (5.87-4.15 m bgs) is characterized by muddy fluvio-limnic sand and numerous wood remains. Pinus and Alnus are evident and suggest bankside conditions. In subzone Koe-16-1a (5.87-5.17 m bgs) amber particles were found, which point to accumulation of reworked material. In subzone Koe-16-1b (5.17-4.15 m bgs), numerous indicators of submerse vegetation occur. Characeae of the genera Chara and Nitella grow in shallow water of good water quality (VEDDER 2004). Potamogeton pectinatus is assumed to be salt water tolerant (Rothmaler 2002). The onset of this submerse vegetation was dated to $12,400 \pm 380 \mathrm{BC}$. Due to the lack of adequate terrestrial plant material, seeds from Potamogeton pectinatus were used. The date is probably much too old due to possible hard-water effects (GEYH 1983) and/or redeposition.

Zone Koe-16-2 (4.15-2.97 m bgs) comprises predominantly telmatic accumulations, i.e. mire deposits. In subzone Koe-16-2a (4.15-3.65 m bgs), numerous wood finds 
and the proof of Coenococcum geophilum confirm the interpretation as carr peat. Finds of Urtica dioica, Lycopus europaeus and Apium cf. graveolens indicate wet, fresh, partly inundated and eu- to mesotrophic conditions (ROTHMALER 2002). Finds of Phragmites australis and Typha angustifolia confirm the existence of reeds after 5,194 \pm 99 BC. Both species tolerate brackish conditions (ROTHMALER 2002). Subzone Koe-16-2b (3.65-2.97 m bgs) consists mainly of peat, only between 3.62 and $3.52 \mathrm{~m}$ bgs a clayey mud is intercalated. Since ca. 5,105 $\pm 83 \mathrm{BC}$, vegetation communities developed under mesotrophic conditions dominated by Schoenoplectus tabernaemontani and Cladium mariscus. Both reed-building species grow under mesotrophic condition on muddy soils in shallow water depths up to ca. $1 \mathrm{~m}$ (Rothmaler 2002). The maximal percentage of Schoenoplectus tabernaemontani was found within the clayey mud, which indicates a temporal inundation of the site. Regular findings of foraminifers until a depth of $1.7 \mathrm{~m}$ bgs prove a marine-brackish influence. A driftline vegetation is indicated by Suaeda maritima and Chenopodium album.

The distinction of zone Koe-16-3 (2.97-0 m bgs) is based on the continuous occurrence of funcus gerardii. Salt meadows developed at the site after 4,747 $\pm 31 \mathrm{BC}$, which grew above sea level and were inundated only episodically (SCHUBERT ET AL. 1995, RothMALER 2002). In subzone Koe-16-3a (2.97-1.45 m bgs), epidermis remains of Phragmites australis are still present. But because diaspores are completely absent, it may be assumed that they belong to rhizomes which penetrated subsequently from higher levels. Diaspores of Androsace cf. septentrionale most probably originate from dry, nutrient-poor and loose basin sand areas in the surroundings of the mire depression. According to Rothmaler (2002) and OBERDORFER (1994), this species grows in sandy dry grasslands as well as on dunes. Although Benkert ET AL. (1996) describe no recent occurrence, some findings from earlier periods have been proven by macro-remain analyses (e. g. LAMPE ET AL. 2005; ENDTMANN, this paper, see Augustenhof site). Both the peat as well as the silt peat of the subzone Koe-16-3b (1.45-0.63 m bgs) are characterized by a significant lack of fossils. All diaspores were mineralized in this section, only resistant charcoal particles remained. Observed Phragmites remains probably penetrated later from younger layers above. LAMPE/JANKE (2004) assume that this section reflects a condensed peat accumulation which degraded and mineralized during two desiccation phases, caused by sl falls at ca. $800 \mathrm{BC}$ and, much more pronounced, during the Little Ice Age between 1,450 and 1,850 AD. In subzone Koe-16-3c funcus gerardii started to occur continuously again. Due to the renewed rise of sl, episodic flooding occured more frequently. The macro-fossil spectrum becomes similar to that of subzone Koer-16-3a. Finds of Phragmites australis diaspores proof the existence of this species, the occurrence of Juncus bufonius points to anthropogenic influence on the salt meadows (Körber-Grohne 1964, RothMALER 2002). The absence of foraminifera is related to the lowered salinity in the Saaler Bodden due to its ongoing truncation from water exchange with the Baltic.

Subsequently the profile was radiocarbon-dated using sampled macro-remains. Due to the scarceness of such remains, the spacing between the samples was rather large and for the upper section no data could be obtained. To

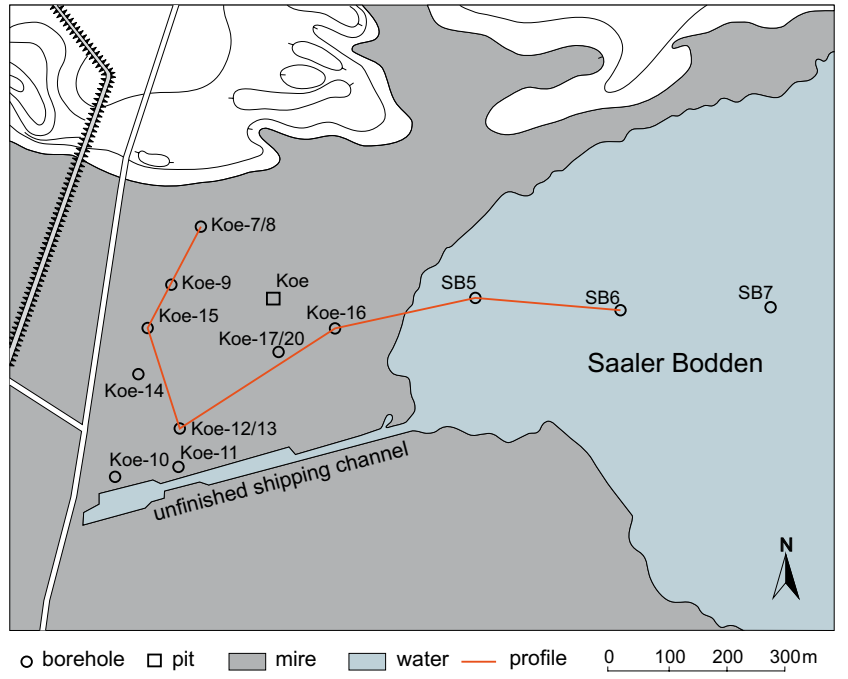

Fig. 2: The Körkwitz coastal mire (Fischland) and the sediment profiles taken to survey depth and sediment distribution. The red line depicts the mire profile shown in fig. 3 .

Abb. 2: Das Küstenüberflutungsmoor Körkwitz (Fischland) sowie Sondierungen zur Erkundung der Moor-Tiefe und Sedimentverteilung. Die rote Linie gibt die Lage des in Abb. 3 gezeigten Moor-Querschnitts wieder.

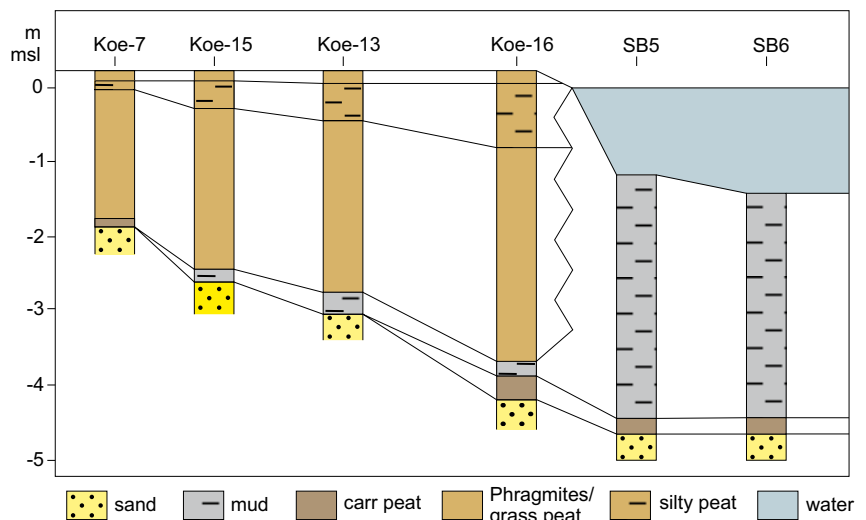

Fig. 3: Selected boreholes from the profile shown in fig. 2 to investigate depth and sediment distribution in the Körkwitz coastal mire (Fischland).

Abb. 3: Ausgewählte Sondierungen, die entlang des in Abb. 2 gezeigten Transekts zur Erkundung der Moor-Tiefe und Sedimentverteilung im Küstenüberflutungsmoor Körkwitz (Fischland) niedergebracht wurden.

obtain a more comprehensive data base of sl rise in this area, the peat profiles Koe-17/20 were taken in the vicinity to Koe-16 (fig. 2). From this profiles, cleaned humic material as bulk samples were used for dating. Bulk samples taken and dated during first surveys were also included (pit Koe, fig. 2). For further expansion of the data base, radiocarbon data available from Fischland (the coastal landscape in which the Körkwitz site is located) and the nearby offshore area were checked for reliability considering find documentation, sediment character, geological position and possible post-sedimentary compaction. The final data base is provided in tab. 1 .

The radiocarbon data cover the depth interval down to $-4 \mathrm{~m}$ msl very well (fig. 8B). Between 0 and 1,000 AD, a gap can be recognized for which no data exist, suggesting that peat growth was apparently low. However, because the da- 


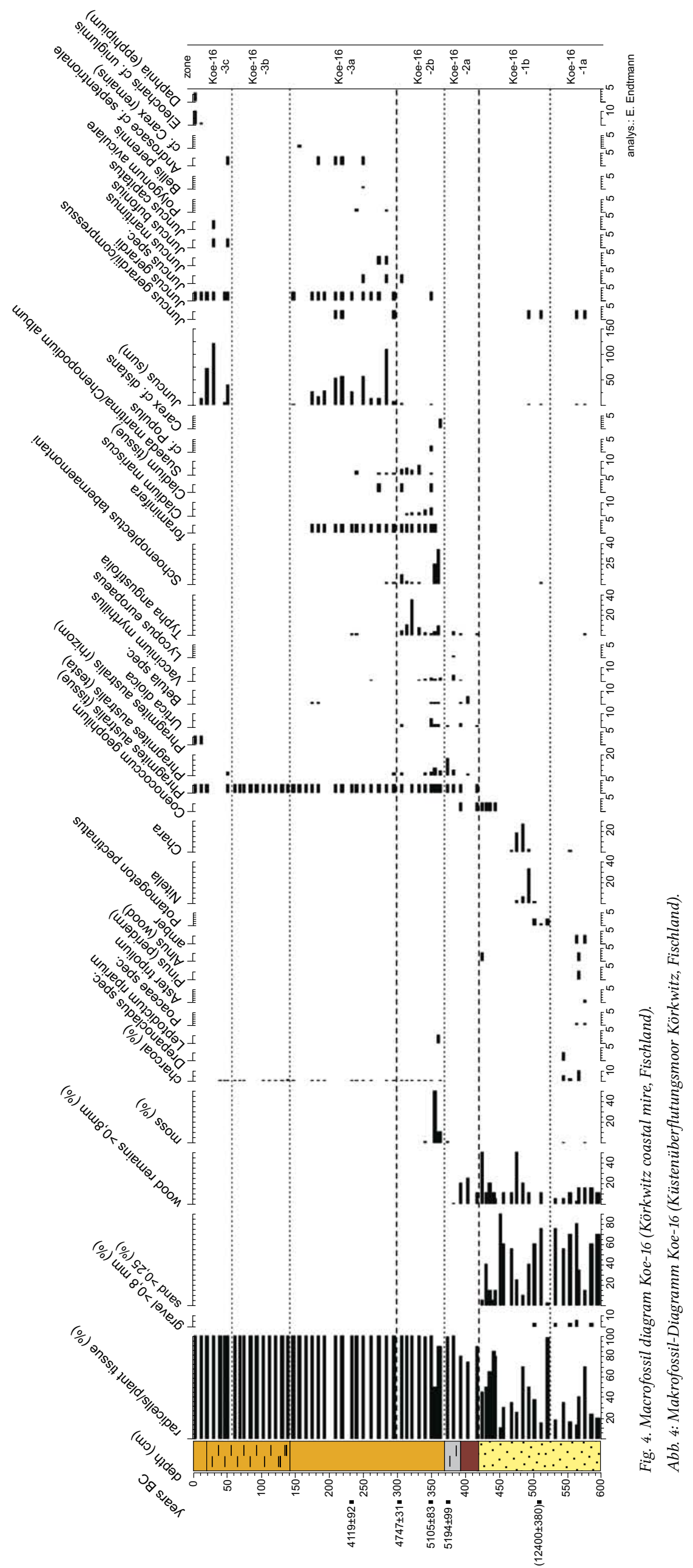


Tab. 1: Radiocarbon data from the Fischland study area. Calibration was made according to DANZEGLOCKE ET AL. (2007), dating error is shown as 1 $\sigma$ confidence interval, msl refers to sample height relative to recent mean sea level, which corresponds to German Ordnance Datum NHN. Lowl and uppl reflects the vertical limits within which the former sl was located according to the facies of the deposits and levelling errors. Lowl is the lower limit and uppl the upper limit relative to the suspected sl. Abbreviation meanings: $t e l m=$ telmatic; mar $=$ marine; terr = terrestrial; indet. $=$ indeterminable; mr = macro-remain, used for dating; ha, leach. res. = humic matter, leaching residue used for dating.

Tab. 1: Radiokohlenstoffdatierungen aus dem Untersuchungsgebiet Fischland. Die Kalibrierung der Daten erfolgte nach DANZEGLOCKE ET AL. (2007), der Datierungsfehler ist als $1 \sigma$ - Intervall angegeben, msl gibt die relative Position der Probe zum derzeitigen mittleren Meeresspiegel wieder, der dem deutschen Höhenbezugsniveau NHN entspricht. Lowl und uppl geben die untere bzw. die obere Grenze des Höhenintervalls wieder, in dem der vormalige Meeresspiegel sich unter Berücksichtigung der sedimentären Fazies und des Bestimmungsfehlers der Höhenlage der Probe gelegen hat. Die Abkürzungen bedeuten telm = telmatisch; mar = marin; terr = terrestrisch; indet. = unbestimmbar; $m r=$ für Datierung wurde ein Makro-Rest genutzt; ha, leach. res. = Huminstoffe, für Datierung wurde der Laugungsrest genutzt.

\begin{tabular}{|c|c|c|c|c|c|c|c|c|c|c|c|c|c|c|c|c|}
\hline No & Lab & code & site, sample & & onv. BF & & & $\mathrm{BC} / \mathrm{A}$ & & & $d^{13} C$ & $\mathrm{msl}$ & lowl & uppl & facies & dated material \\
\hline 1 & KIA & 25991 & Körkwitz 20/1 & $>1954$ & & & $>1954$ & & & $A D$ & -29.9 & -0.1 & -0.5 & 0.1 & telm & ha, leach.res. \\
\hline 2 & $\mathrm{Hv}$ & 23976 & Körkwitz & 355 & $+1-$ & 85 & 1547 & $+1-$ & 79 & $A D$ & -28.7 & 0.0 & -0.5 & 0.1 & telm & peat, bulk \\
\hline 3 & $\mathrm{Hv}$ & 23673 & Körkwitz & 595 & $+1-$ & 65 & 1351 & $+1-$ & 45 & $\mathrm{AD}$ & -27.8 & -0.1 & -0.5 & 0.1 & telm & peat, bulk \\
\hline 4 & $\mathrm{Hv}$ & 23675 & Körkwitz & 710 & $+1-$ & 80 & 1296 & $+/-$ & 70 & $\mathrm{AD}$ & -28.1 & -0.1 & -0.5 & 0.1 & telm & peat, bulk \\
\hline 5 & $\mathrm{KIA}$ & 25992 & Körkwitz 20/1 & 780 & $+1-$ & 25 & 1242 & $+/-$ & 18 & $A D$ & -27.1 & -0.1 & -0.5 & 0.1 & telm & ha, leach.res. \\
\hline 6 & $\mathrm{Hv}$ & 23674 & Körkwitz & 820 & $+/-$ & 80 & 1168 & $+/-$ & 83 & $A D$ & -28.2 & -0.1 & -0.5 & 0.1 & telm & peat, bulk \\
\hline 7 & KIA & 25993 & Körkwitz 20/1 & 2175 & $+1-$ & 25 & 271 & $+1-$ & 69 & $\mathrm{BC}$ & -28.9 & -0.2 & -0.5 & 0.1 & telm & ha, leach.res. \\
\hline 8 & $\mathrm{Hv}$ & 23677 & Körkwitz & 2410 & $+/-$ & 90 & 569 & $+/-$ & 141 & $\mathrm{BC}$ & -28.1 & -0.4 & -0.5 & 0.1 & telm & peat, bulk \\
\hline 9 & $\mathrm{Hv}$ & 23676 & Körkwitz & 2555 & $+1-$ & 70 & 670 & $+1-$ & 112 & $\mathrm{BC}$ & -27.0 & -0.5 & -0.5 & 0.1 & telm & peat, bulk \\
\hline 10 & KIA & 25994 & Körkwitz 20/1 & 2745 & $+1-$ & 30 & 885 & $+/-$ & 33 & $\mathrm{BC}$ & -27.5 & -0.8 & -0.5 & 0.1 & telm & ha, leach.res. \\
\hline 11 & KIA & 25995 & Körkwitz 20/1 & 3225 & $+1-$ & 30 & 1490 & $+1-$ & 30 & $\mathrm{BC}$ & -29.3 & -0.9 & -0.5 & 0.1 & telm & ha, leach.res. \\
\hline 12 & KIA & 22884 & Körkwitz17-19 & 3611 & $+1-$ & 54 & 1976 & $+/-$ & 74 & $\mathrm{BC}$ & -26.7 & -1.0 & -0.5 & 0.1 & telm & indet mr \\
\hline 13 & KIA & 25996 & Körkwitz २૦/1 & 3835 & $+/-$ & 30 & 2306 & $+1-$ & 71 & $\mathrm{BC}$ & -28.7 & -1.1 & -0.5 & 0.1 & telm & ha, leach.res. \\
\hline 14 & KIA & 25997 & Körkwitz २૦/1 & 4095 & $+1-$ & 30 & 2713 & $+1-$ & 112 & $\mathrm{BC}$ & -27.9 & -1.3 & -0.5 & 0.1 & telm & ha, leach.res. \\
\hline 15 & $\mathrm{KIA}$ & 25998 & Körkwitz 20/1 & 4390 & $+/-$ & 30 & 3008 & $+/-$ & 61 & $\mathrm{BC}$ & -26.9 & -1.5 & -0.5 & 0.1 & telm & ha, leach.res. \\
\hline 16 & $\mathrm{Gd}$ & 15284 & Körkwitz & 4490 & $+1-$ & 100 & 3182 & $+/-$ & 149 & $\mathrm{BC}$ & - & -1.1 & -0.5 & 0.1 & telm & peat, bulk \\
\hline 17 & KIA & 26001 & Körkwitz २० & 4550 & $+/-$ & 25 & 3251 & $+/-$ & 103 & $\mathrm{BC}$ & -28.2 & -1.6 & -0.5 & 0.1 & telm & ha, leach.res. \\
\hline 18 & $\mathrm{KIA}$ & 25999 & Körkwitz 20/1 & 4655 & $+/-$ & 30 & 3445 & $+/-$ & 52 & $\mathrm{BC}$ & -26.6 & -1.7 & -0.5 & 0.1 & telm & ha, leach.res. \\
\hline 19 & KIA & 22883 & Körkwitz17-19 & 4657 & $+/-$ & 56 & 3455 & $+/-$ & 70 & $\mathrm{BC}$ & -27.0 & -1.8 & -0.5 & 0.1 & telm & indet mr \\
\hline २० & KIA & 26002 & Körkwitz २० & 4920 & $+/-$ & 30 & 3699 & $+1-$ & 32 & $\mathrm{BC}$ & -25.6 & -1.9 & -0.5 & 0.1 & telm & ha, leach.res. \\
\hline 21 & KIA & 26000 & Körkwitz 20/1 & 4920 & $+/-$ & 30 & 3699 & $+1-$ & 32 & $\mathrm{BC}$ & -25.3 & -1.9 & -0.5 & 0.1 & telm & ha, leach.res. \\
\hline २2 & KIA & 22882 & Körkwitz16 & 5285 & $+/-$ & 65 & 4119 & $+/-$ & 92 & $\mathrm{BC}$ & -26.0 & -2.1 & -0.5 & 0.1 & telm & indet. mr \\
\hline 23 & KIA & 26003 & Körkwitz २૦ & 5325 & $+1-$ & 30 & 4154 & $+1-$ & 66 & $\mathrm{BC}$ & -25.3 & -2.5 & -0.5 & 0.1 & telm & ha, leach.res. \\
\hline 24 & KIA & 26004 & Körkwitz 20 & 5845 & $+1-$ & 30 & 4726 & $+1-$ & 36 & $\mathrm{BC}$ & -25.7 & -3.1 & -0.5 & 0.1 & telm & ha, leach.res. \\
\hline 25 & KIA & 22881 & Körkwitz16 & 5881 & $+1-$ & 36 & 4747 & $+1-$ & 31 & $\mathrm{BC}$ & -22.1 & -2.8 & -0.5 & 0.1 & telm & mr [Schoenopl.] \\
\hline 26 & KIA & 26005 & Körkwitz २० & 6135 & $+1-$ & 35 & 5106 & $+1-$ & 78 & $\mathrm{BC}$ & -27.1 & -3.7 & -0.5 & 0.1 & telm & ha, leach.res. \\
\hline 27 & $\mathrm{KIA}$ & 22880 & Körkwitz16 & 6150 & $+1-$ & 40 & 5105 & $+/-$ & 83 & $\mathrm{BC}$ & -25.5 & -3.3 & -0.5 & 0.1 & telm & mr [Schoenopl.] \\
\hline 28 & KIA & 22879 & Körkwitz16 & 6255 & $+/-$ & 74 & 5194 & $+1-$ & 99 & $\mathrm{BC}$ & -26.4 & -3.5 & -0.5 & 0.1 & telm & $\mathrm{mr}$ [insect remains] \\
\hline 29 & KIA & 26006 & Körkwitz 20 & 6475 & $+/-$ & 30 & 5436 & $+1-$ & 40 & $\mathrm{BC}$ & -28.1 & -4.2 & -0.5 & 0.1 & telm & ha, leach.res. \\
\hline 30 & $\mathrm{Hv}$ & 22398 & $\operatorname{Darß} 1 * *$ & 6520 & $+1-$ & २2० & 5438 & $+1-$ & 204 & $\mathrm{BC}$ & - & -7.0 & -0.8 & 0.2 & $?$ & sandy mud, bulk \\
\hline 31 & KIA & 26573 & SaalerB 7/2 & 6670 & $+/-$ & 35 & 5596 & $+/-$ & 29 & $\mathrm{BC}$ & -28.4 & -3.9 & -0.8 & 0.2 & telm & Pinus bark \\
\hline 32 & $\mathrm{KIA}$ & 35288 & Grabow, Pr. 16* & 7100 & $+/-$ & 35 & 5974 & $+/-$ & 39 & $\mathrm{BC}$ & -26.7 & -6.8 & -0.8 & 0.2 & telm & peat, bulk \\
\hline 33 & KIA & 35275 & SundWiese, Pr. $1^{*}$ & 7195 & $+1-$ & 40 & 6058 & $+/-$ & 30 & $\mathrm{BC}$ & -27.1 & -7.3 & -0.5 & & terr & wood from fossil soil \\
\hline 34 & KIA & 35282 & nördl. Zingst, Pr. 10* & 7395 & $+1-$ & 40 & 6295 & $+/-$ & 53 & $B C$ & -18.5 & -9.5 & -0.8 & 0.2 & telm & indet mr \\
\hline 35 & $\mathrm{Hv}$ & 22399 & $\operatorname{Darß} 1^{* *}$ & 7485 & $+/-$ & 115 & 6338 & $+1-$ & 101 & $\mathrm{BC}$ & - & -9.7 & -0.8 & 0.2 & telm & peat, bulk \\
\hline 36 & & & DS F $3750 / 13 a^{* * *}$ & 7760 & $+/-$ & 115 & 6653 & $+1-$ & 146 & $\mathrm{BC}$ & - & -11.7 & -0.8 & 0.2 & telm & peat, bulk \\
\hline 37 & & & DS F $3300 / 12 * * *$ & 7990 & $+/-$ & 100 & 6893 & $+/-$ & 145 & $\mathrm{BC}$ & - & -16.2 & -0.8 & 0.2 & telm & peat, bulk \\
\hline 38 & KIA & 22878 & Körkwitz16 & 12288 & $+/-$ & 68 & 12400 & $+/-$ & 380 & $\mathrm{BC}$ & -10.0 & -4.8 & -0.5 & 0.1 & telm & mr [Potamogeton] \\
\hline
\end{tabular}

* data provided by M. Naumann, LBEG Hannover

** data provided by W. Schumacher, Greifswald University

*** data provided by W. Lemke $\dagger$

ta derive from different sites (Koe, Koe-16 and Koe-17/20) and even in a flat salt meadow height differences of a few decimetres are not exceptional, we cannot conclude that a sl stillstand or fall has occurred. For the interval deeper than $-4 \mathrm{~m}$ only scarce data exist. In the near future more data will be come available due to the recent findings of drowned forests offshore (TAUBER subm.). So far, we can add only eight unpublished dates from Fischland and its offshore area. The dated materials are bulk samples from basal peat, macro-remains sampled from basal peat or wood from a fossil soil. Although the character of the accumulations is not known in all details, they are interpreted as basal sediments reflecting the former sl (see tab. 1). Their positions allow us to extend the rsl curve down to $-12 \mathrm{~m}$ msl as shown in fig $8 \mathrm{~B}$. 


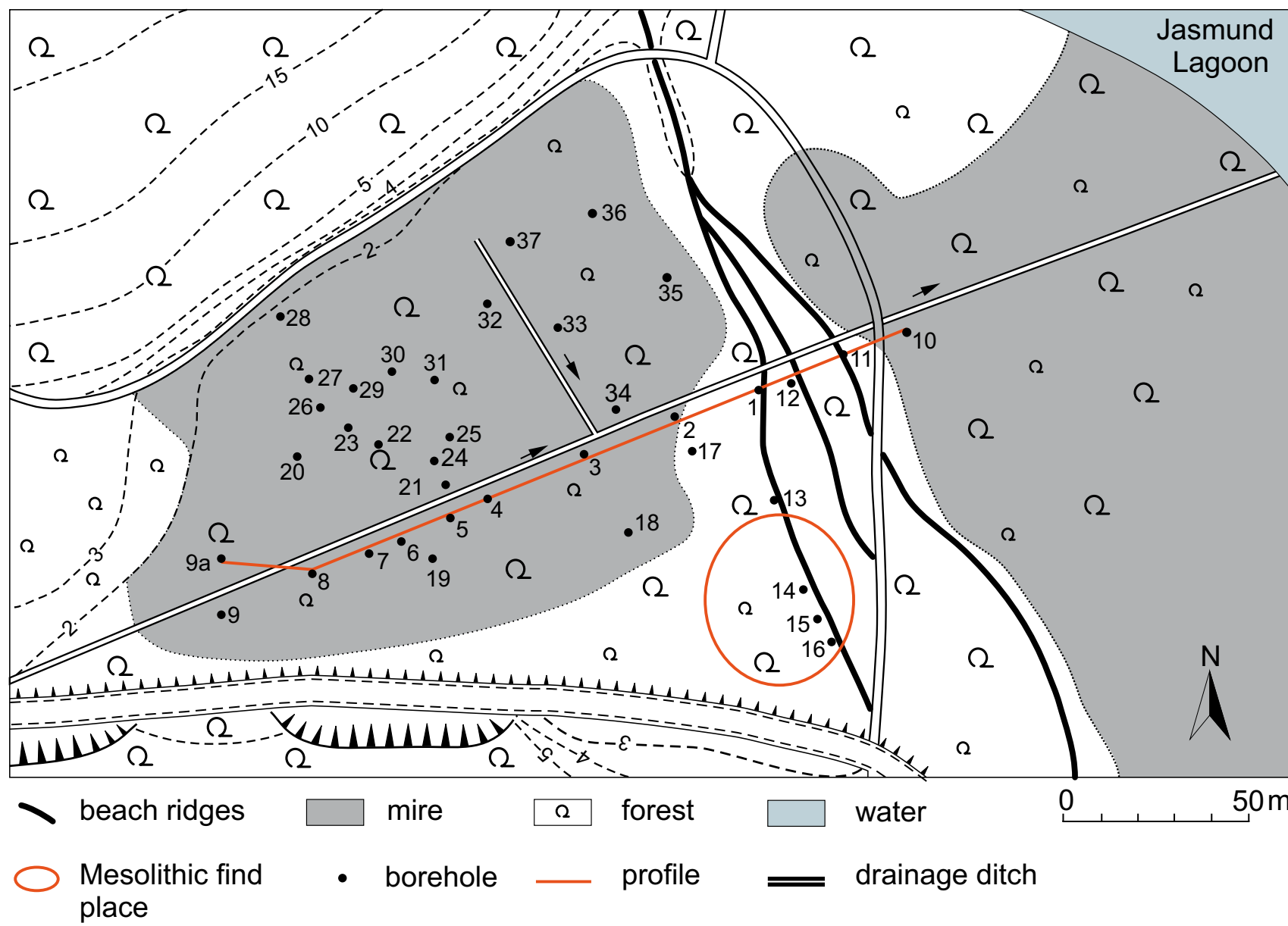

Fig. 5: The Augustenhof coastal mire (North Rügen/Hiddensee), the sediment profiles surveyed and the core Aug-9a used for sampling. The red line depicts the mire profile shown in fig. 6.

Abb. 5: Das Küstenüberflutungsmoor Augustenhof (Nord-Rügen/Hiddensee), Sedimentsondierungen und Lage des beprobten Kerns Aug-9a. Die rote Linie gibt die Lage des in Abb. 6 gezeigten Moor-Querschnitts wieder.

\section{Augustenhof study site [North Rügen/Hiddensee]}

The study site Augustenhof is a small coastal mire located at the southern shore of the Großer Jasmunder Bodden (figs. 1, 5), which is dammed by a beach ridge system from the lagoon. Since 1914 the ridges are known as a find spot of late Mesolithic artefacts and belong to a cluster of similar places known from the vicinity on Rügen and the adjacent mainland (UMbreIt 1939, Gramsch 1978, Terberger/ SEILER 2005). A pollen diagram was published by LANGE ET AL. (1986). The mire was surveyed by 37 boreholes (fig. 5) to investigate the depression's depth and sediment distribution. A profile along the central ditch, which drains the mire today is shown in fig. 6 .

The base of the depression lies at about -4.5 to $-5.5 \mathrm{~m}$ msl and consists of sand of various grain sizes. In most boreholes, a basal peat was detected upon which marine mud with shell remains were deposited. Shortly after the inundation by the rising sea, beach ridges started to cut the depression off from the sea. First ridge sediments occur in borehole 5 at -4.1 to $-3.25 \mathrm{~m} \mathrm{msl}$, with a coarser grained continuation in borehole 4 . Subsequently the ridges started to prograde eastwards, thereby climbing to higher positions (boreholes 3,2,1). Consequently, the cut-off must have become effective, as behind the beach ridge a small coastal lake developed. In its central part marl accumulated (borehole 6), while at the seaward margin organic mud was intersected by sandy overwash layers (borehole 5). While the beach ridge prograded to the NE, the lake area shrunk due to peat growth. From ca. $-1 \mathrm{~m}$ msl upwards, peat is the only sediment in the depression behind the ridges. The sequence proves that primarily the peat grew with rising sl. However, the disappearance of the lake points to some lateral growth too, and the present surface about 1 to 1.5 $\mathrm{m}$ above msl clearly shows that water input from the surrounding elevations allowed a subsequent growth independent of sl position. The recent drainage of the fen must have initiated peat decomposition, compaction and surface lowering. Nevertheless, together with the neighbouring and very similar site Ralswiek (KLIEwE/LANGE 1971), the mire represents the only site on North Rügen where peat growth was controlled by the rising sea at least for several vertical metres.

Borehole Aug-9a, which has not been influenced by lake or beach ridge development, was selected to take samples for macro-remain analysis and radiocarbon dating. According to the results of the macro-remain analysis, the sequence can be divided into four zones with several subzones (fig. 7). In zone Aug-9a-1 (5.00-4.49 m bgs, surface is $1.26 \mathrm{~m}$ above $\mathrm{msl}$ ), the underlaying silicate mud is nearly barren of macrofossils and only some remains of indeterminable molluscs were detected. The sedimentation 


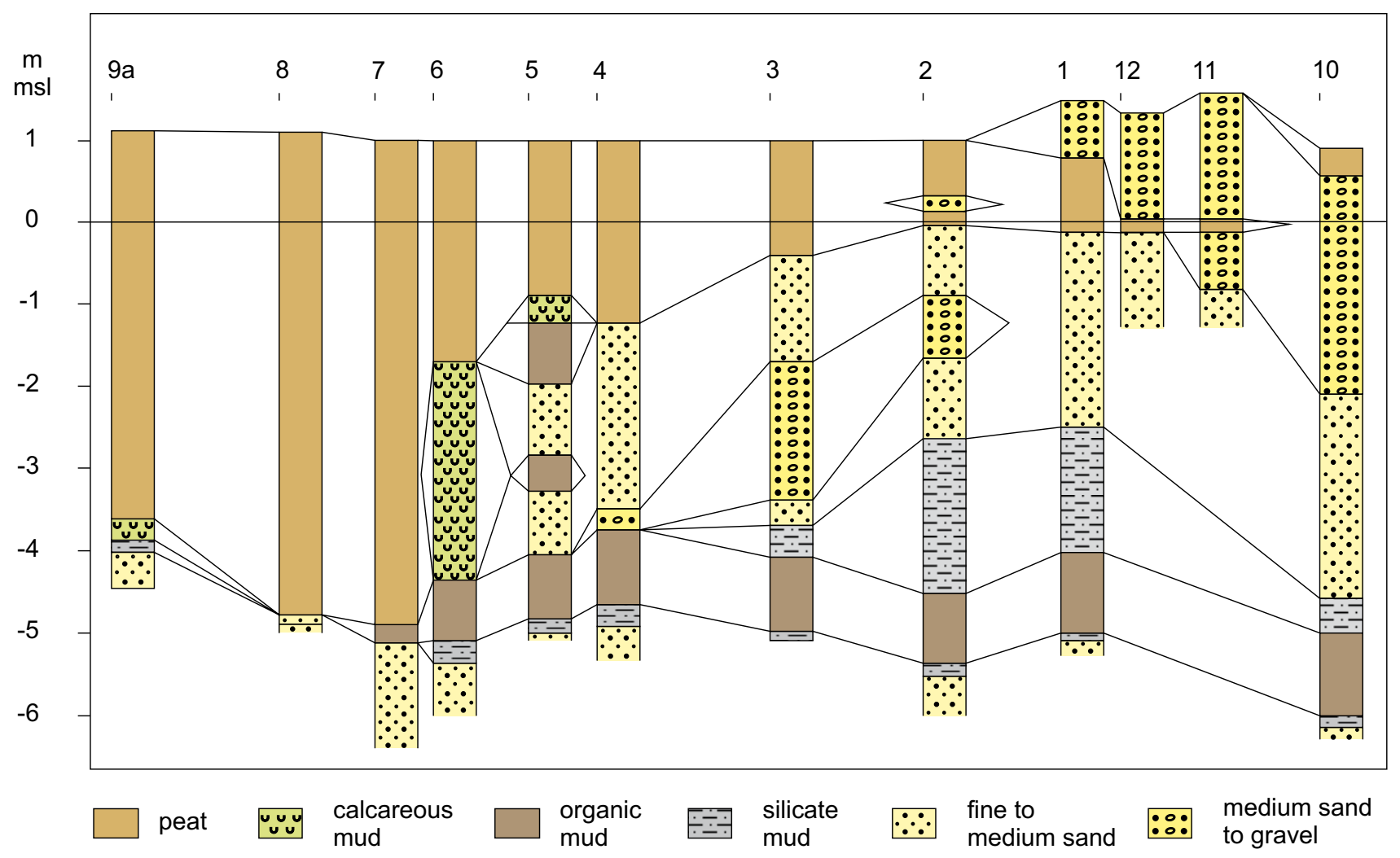

Fig. 6: Selected boreholes from the profile shown in fig. 5 to investigate depth and sediment distribution in the Augustenhof coastal mire (North Rügen/Hiddensee).

Abb. 6: Ausgewählte Sondierungen, die entlang des in Abb. 5 gezeigten Transekts zur Erkundung der Moor-Tiefe und Sedimentverteilung im Küstenüberflutungsmoor Augustenhof (Nord-Rügen/Hiddensee) niedergebracht wurden.

of calcareous mud (4.91-4.49 m bgs) reflects the existence of open water. The macrofossil spectrum comprises wood and charcoal particles (probably redeposited) and rootlets which extended down from higher strata.

With the onset of carr peat deposition in zone Aug-9a-2 (4.49-3.49 m bgs) the portion of rootlets and wood remains increases significantly. Numerous remains of Alnus glutinosa point probably to the existence of Alnion glutinosae (Malc. 1929) Meijer-Drees 1936 (SCHUberT ET AL. 1995). Caltha palustris, Chrysosplenium alternifolium, Apium graveolens, Mentha aquatica and Eupatorium cannabinum probably grew along a creek. These species and Urtica dioica are characteristic of eutrophic soil conditions. The continuous occurrence of mosses like Brachythecium spec. and Homalothecium nitens also points to the existence of wet soil or spring water conditions. Leptodictium riparium and Scorpidium scorpidioides represent stagnant water.

The following zone Aug-9a-3 (3.49-2.55 m bgs) is dominated by species which are also characteristic of recent reed vegetation. In the lower section, peat was formed mainly by Phragmites australis and Schoenoplectus tabernaemontanii. Since 4,652 \pm 65 BC Cladium mariscus also becomes evident. All species reflect mesotrophic conditions and shallow water. The occurrence of foraminifers and S. tabernaemontanii indicate brackish-marine influence, which in turn implies that identified Typha seeds must derive from the halotolerant species T. angustifolia (Rothmaler 2002). Decreasing amounts of Schoenoplectus tabernaemontanii, increasing amounts of Cladium mariscus and the absence of foraminifers show stronger freshwater influence to- wards upper part of the zone. Regular finds of Chenopodium album/Suaeda maritima and also of Atriplex spec. point to the existence of eutrophic drift line communities in the surroundings. A single find of Androsace cf. septentrionale at about 5,160 $\pm 65 \mathrm{BC}$ is remarkable. Former occurrences in habitats along the coastal area of the Saaler Bodden (profile Körkwitz, Endtmann 2006) and the Strelasund (profile Stralsund-Mischwasserspeicher, ENDTMANN, unpublished data) date younger than 5,000 BC. Finds along the coast area of Wismar bay (profile Redentin; LAmPE et al. 2005) date between $322 \pm 51 \mathrm{AD}$ and $1,809 \pm 97 \mathrm{AD}$. At the moment, the Augustenhof finding is the oldest one along the NE German Baltic coast. Androsace septentrionale grows on mesotrophic loose sandy soils, ruderal habitats and also on dunes (ROTHMALER 2002).

Soon after 3,864 $\pm 93 \mathrm{BC}$, an alder forest swamp peat is developed again (zone Aug-9a-4; 2.55-0.00 m bgs). The macro-fossil spectrum is similar to zone Aug-9-2. Wooden particles and radicells are predominant. Zone Aug-9a-4 is subdivided into 3 subzones. In subzone Aug-9a-4a (2.55-1.45 m bgs) the abundance of alder remains is higher than before but not as high as in zone Aug-9a-2. Urtica dioica occurs continuously but in low percentages. Caltha palustris, Mentha spec. and Apium graveolens grow on eutrophic soils along the creek. The absence of Phragmites australis in subzone Aug-9a-4b (1.45-0.85 m bgs) reflects a change of water table and dryer conditions than before. Numerous diaspores of Urtica dioica point to a release of nutrients by peat degradation. Eutrophic, partly muddy sites along the creek are represented by Berula erecta and Lythrum sali- 


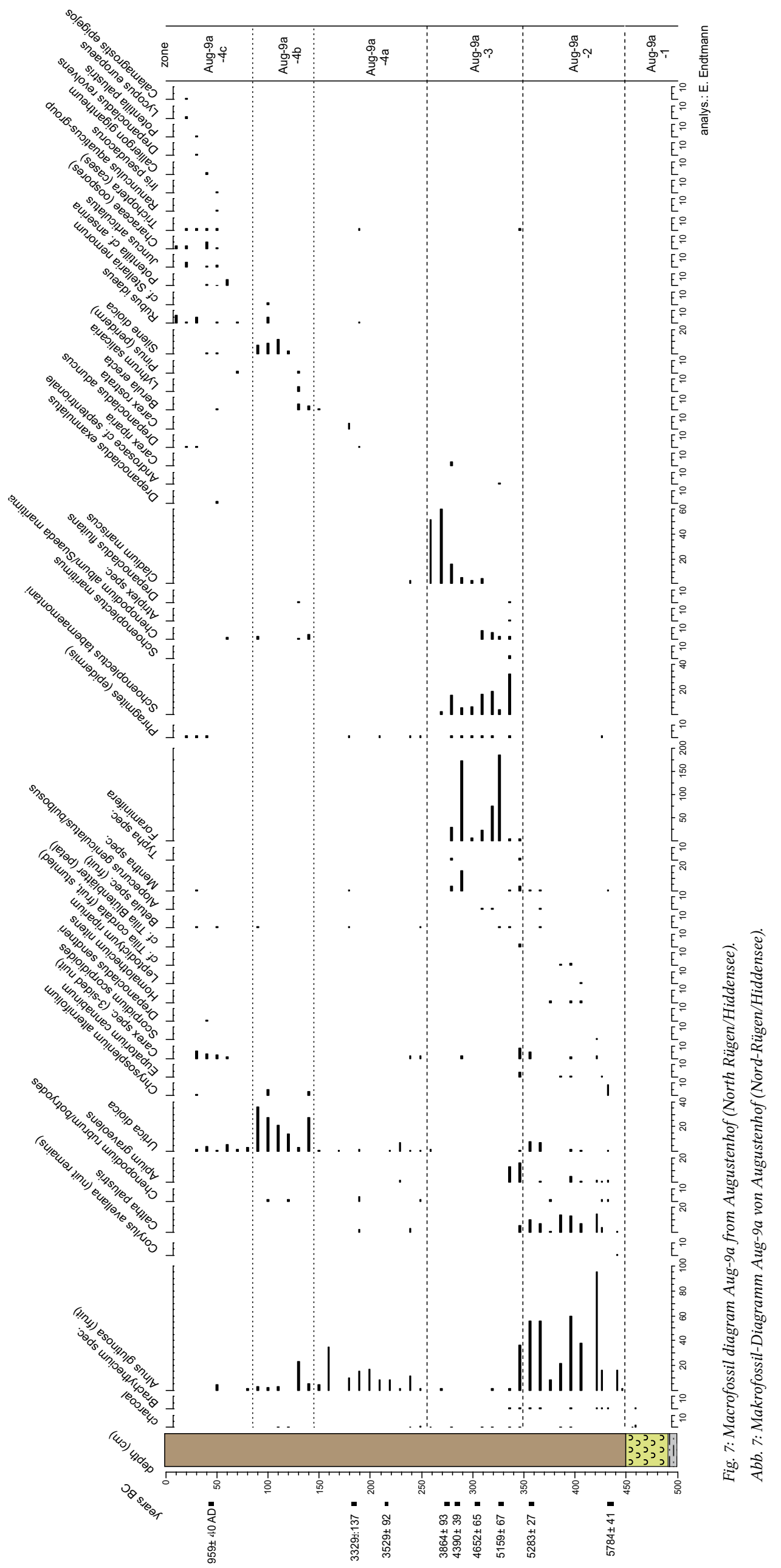


caria. Silene dioica, Rubus idaeus and cf. Stellaria nemorum are also associated with nutrient enrichment. Seeds of cf. Potentilla anserina and Chenopodium album/Suaeda maritima reflect the existence of a eutrophic drift line vegetation with nutrient-enriched conditions along the shoreline of the lagoon. Subzone Aug-9a-4c (0.85-0.00 m bgs) represents an Urtico-Alnetum glutinosae (Scam.1935) Fuk. 1961 (Schubert et al. 1995) with Alnus glutinosa, Urtica dioica and Rubus idaeus. Iris pseudacorus also points to a eutrophic alder swamp, but with episodically flooded hummocks and hollows. Finds of different species of Drepanocladus,
Characeae oospores, and diaspores of Ranunculus Batrachium-group and cases of caddisflies (Trichoptera) reflect the existence of shallow fresh or brackish water nearby.

The macro-remain analysis clearly shows that the site was influenced by intrusions of brackish water and that the rising sea instigated peat growth until 4,390 $\pm 39 \mathrm{BC}$; since ca. 3,850 BC the site became dryer. After a period of peat degradation, which started probably at about 3,000 BC, water discharged from the surrounding hills became more important for peat growth control. The mire grew to at least $1 \mathrm{~m}$ above sea level, which is the lowest mire surface alti-

Tab. 2: Radiocarbon data from the N-Rügen / Hiddensee study area. For details and abbreviations see tab. 1.

Tab. 2: Radiokohlenstoffdatierungen aus dem Untersuchungsgebiet N-Rügen/Hiddensee. Für Details und Abkürzungen siehe Tab. 1.

\begin{tabular}{|c|c|c|c|c|c|c|c|c|c|c|c|c|c|c|c|c|}
\hline \multirow{2}{*}{$\frac{\text { No }}{1}$} & \multirow{2}{*}{$\begin{array}{l}\text { Lab } \\
\mathrm{HV}\end{array}$} & \multirow{2}{*}{$\begin{array}{l}\text { code } \\
24430\end{array}$} & \multirow{2}{*}{$\begin{array}{l}\text { site, sample } \\
\text { Hiddensee } 2\end{array}$} & \multicolumn{3}{|c|}{ conv. BP } & \multicolumn{3}{|c|}{ calBC/AD } & \multirow{2}{*}{\multicolumn{2}{|c|}{$\frac{\mathbf{d}^{\mathbf{1 3}} \mathbf{C}}{-17.6}$}} & \multirow{2}{*}{$\frac{\mathbf{m s l}}{-0.5}$} & \multirow{2}{*}{$\begin{array}{l}\text { lowl } \\
-0.8\end{array}$} & \multirow{2}{*}{$\begin{array}{c}\text { uppl } \\
0.2\end{array}$} & \multirow{2}{*}{$\begin{array}{l}\text { facies } \\
\text { telm }\end{array}$} & \multirow{2}{*}{$\begin{array}{l}\text { dated material } \\
\text { peat, bulk }\end{array}$} \\
\hline & & & & 595 & $+1-$ & 65 & 1351 & $+1-$ & 45 & & & & & & & \\
\hline 2 & KIA & 25987 & Augustenhof $\mathrm{AHGa}$ & 1065 & $+1-$ & 30 & 959 & $+1-$ & 40 & $\mathrm{AD}$ & -26.7 & 0.8 & -0.5 & 0.1 & telm & indet $\mathrm{mr}$ \\
\hline 3 & $\mathrm{Hv}$ & 23672 & Vaschwitz & 1120 & $+/-$ & 100 & 889 & $+/-$ & 106 & $\mathrm{AD}$ & -28.8 & 0.0 & -0.8 & 0.2 & telm & peat, bulk \\
\hline 4 & $\mathrm{Hv}$ & 23671 & Vaschwitz & 1155 & $+/-$ & 100 & 857 & $+1-$ & 109 & $\mathrm{AD}$ & -28.5 & 0.0 & -0.8 & 0.2 & telm & peat, bulk \\
\hline 5 & KIA & 26574 & Vaschwitz & 1440 & $+1-$ & 25 & 613 & $+1-$ & २० & $\mathrm{AD}$ & -31.2 & 0.0 & -0.8 & 0.2 & telm & peat, bulk \\
\hline 6 & KIA & 26575 & Vaschwitz & 2755 & $+1-$ & 45 & 909 & $+1-$ & 54 & $\mathrm{BC}$ & -27.9 & -0.1 & -0.8 & 0.2 & telm & peat, bulk \\
\hline 7 & KIA & 19818 & Feuersteinfelder Nord & 3890 & $+1-$ & 30 & 2386 & $+1-$ & 56 & $\mathrm{BC}$ & -27.6 & 0.0 & -0.8 & 0.2 & telm & mr [Chenopodium] \\
\hline 8 & $\mathrm{Hv}$ & 24832 & Feuersteinfelder Nord & 4240 & $+1-$ & 70 & 2808 & $+1-$ & 101 & $\mathrm{BC}$ & -27.6 & -0.1 & -0.8 & 0.2 & telm & peat, bulk \\
\hline 9 & KIA & 26577 & Vaschwitz & 4290 & $+1-$ & 50 & 2939 & $+1-$ & 52 & $\mathrm{BC}$ & -28.7 & -0.4 & -0.8 & 0.2 & telm & peat, bulk \\
\hline 10 & KIA & 26576 & Vaschwitz & 4300 & $+/-$ & 40 & 2944 & $+1-$ & 44 & $\mathrm{BC}$ & -28.6 & -0.4 & -0.8 & 0.2 & telm & peat, bulk \\
\hline 12 & KIA & 25989 & Augustenhof AH9a & 4580 & $+1-$ & 30 & 3329 & $+1-$ & 137 & $\mathrm{BC}$ & -28.5 & -0.3 & -0.5 & 0.1 & telm & mr [A.glutinosa] \\
\hline 13 & KIA & 24217 & Lietzow-Buddelin *** & 4632 & $+/-$ & 38 & 3435 & $+1-$ & 58 & $\mathrm{BC}$ & -23.2 & -0.2 & -0.5 & & terr & bone \\
\hline 14 & KIA & 26563 & Augustenhof $\mathrm{AHGa}$ & 4770 & $+1-$ & 50 & 3529 & $+1-$ & 92 & $\mathrm{BC}$ & -29.6 & -0.9 & -0.5 & 0.1 & telm & mr [A.glutinosa] \\
\hline 15 & KIA & 25985 & Augustenhof AH5b & 5030 & $+1-$ & 35 & 3849 & $+/-$ & 69 & $\mathrm{BC}$ & -27.2 & -1.0 & -0.5 & 0.1 & telm & mr [A.glutinosa] \\
\hline 16 & KIA & 26565 & Augustenhof AH9a & 5080 & $+/-$ & 90 & 3864 & $+1-$ & 93 & $\mathrm{BC}$ & -30.3 & -1.5 & -0.5 & 0.1 & telm & mr [Carex riparia] \\
\hline 17 & KIA & 24220 & Lietzow-Buddelin *** & 5324 & $+1-$ & 39 & 4156 & $+1-$ & 70 & $\mathrm{BC}$ & -22.8 & -0.4 & -0.5 & & terr & antler fragment \\
\hline 18 & KIA & 24218 & Lietzow-Buddelin *** & 5368 & $+1-$ & 38 & 4209 & $+1-$ & 92 & $\mathrm{BC}$ & -23.6 & -0.6 & -0.5 & & terr & bone \\
\hline 19 & KIA & 24245 & Bergen Fpl. 24, Breetzer Ort * & 5393 & $+1-$ & 29 & 4281 & $+1-$ & 35 & $\mathrm{BC}$ & -27.5 & -1.1 & & 0.5 & mar & wooden post \\
\hline २० & KIA & 26566 & Augustenhof AH9a & 5530 & $+1-$ & 35 & 4390 & $+/-$ & 39 & $\mathrm{BC}$ & -24.3 & -1.6 & -0.5 & 0.1 & telm & mr [Cladium/Schoenopl.] \\
\hline २० & KIA & 24219 & Lietzow-Buddelin *** & 5645 & $+/-$ & 39 & 4472 & $+/-$ & 49 & $\mathrm{BC}$ & -23.9 & -0.7 & -0.5 & & terr & bone \\
\hline 21 & KIA & 24249 & Bergen Fpl. 24, Breetzer Ort * & 5704 & $+1-$ & 30 & 4544 & $+/-$ & 40 & $\mathrm{BC}$ & -21.8 & -1.1 & & 0.5 & mar & Cervus bone \\
\hline 22 & KIA & 24248 & Bergen Fpl. 24, Breetzer Ort* & 5802 & $+1-$ & 30 & 4657 & $+1-$ & 42 & $\mathrm{BC}$ & -21.3 & -1.1 & & 0.5 & mar & Sus bone \\
\hline 23 & KIA & 26567 & Augustenhof $\mathrm{AH9a}$ & 5810 & $+/-$ & 55 & 4652 & $+/-$ & 65 & $\mathrm{BC}$ & -31.1 & -1.8 & -0.5 & 0.1 & telm & mr [Chenopodium] \\
\hline 24 & Bln & 1559 & $\left.\operatorname{Binz}\right|^{* * * *}$ & 5844 & $+/-$ & 70 & 4702 & $+1-$ & 87 & $\mathrm{BC}$ & - & -1.9 & -0.8 & 0.2 & telm & peat, bulk \\
\hline 25 & KIA & 24250 & Bergen Fpl. 24, Breetzer Ort* & 5879 & $+/-$ & 35 & 4756 & $+/-$ & 33 & $\mathrm{BC}$ & -23.1 & -1.4 & & 0.5 & mar & Capreolus bone \\
\hline 26 & KIA & 25986 & Augustenhof AH5b & 5980 & $+/-$ & 35 & 4873 & $+1-$ & 49 & $\mathrm{BC}$ & -26.0 & -2.2 & -0.5 & 0.1 & telm & indet $\mathrm{mr}$ \\
\hline 27 & KIA & 27247 & Wittow Fpl. 100 * & 6005 & $+/-$ & 26 & 4898 & $+1-$ & 38 & $\mathrm{BC}$ & -26.0 & -1.8 & & 0.5 & mar & wood \\
\hline 28 & KIA & 24246 & Bergen Fpl. 24, Breetzer Ort* & 6181 & $+1-$ & 35 & 5136 & $+1-$ & 58 & $\mathrm{BC}$ & -26.0 & -1.1 & -0.5 & & terr & trunk \\
\hline 29 & KIA & 26568 & Augustenhof $\mathrm{AHGa}$ & 6205 & $+1-$ & 35 & 5159 & $+1-$ & 67 & $\mathrm{BC}$ & -27.7 & -2.0 & -0.5 & 0.1 & telm & indet $\mathrm{mr}$ \\
\hline 30 & KIA & 26569 & Augustenhof $\mathrm{AHGa}$ & 6300 & $+1-$ & 30 & 5283 & $+/-$ & 27 & $\mathrm{BC}$ & -27.4 & -2.3 & -0.5 & 0.1 & telm & mr [A.glutinosa] \\
\hline 31 & KIA & 24247 & Bergen Fpl. 24, Breetzer Ort* & 6574 & $+1-$ & 35 & 5528 & $+1-$ & 29 & $\mathrm{BC}$ & -26.2 & -1.1 & -0.5 & & terr & charcoal, fireplace \\
\hline 32 & KIA & 27248 & Wittow Fpl. 100, Kamminer Ort * & 6577 & $+/-$ & 32 & 5529 & $+1-$ & 27 & $\mathrm{BC}$ & -25.4 & -1.7 & -0.5 & & terr & wood \\
\hline 33 & $\mathrm{Hv}$ & 24432 & Breezer Bodden 1/1 & 6700 & $+1-$ & 90 & 5621 & $+1-$ & 72 & $\mathrm{BC}$ & -25.7 & -3.5 & -0.8 & 0.2 & telm & peat, bulk \\
\hline 34 & $\mathrm{Hv}$ & 24433 & Breezer Bodden & 6840 & $+1-$ & 100 & 5754 & $+1-$ & 92 & $\mathrm{BC}$ & -27.0 & -3.7 & -0.8 & 0.2 & telm & peat, bulk \\
\hline 35 & KIA & 26571 & Augustenhof $\mathrm{AHGa}$ & 6905 & $+/-$ & 45 & 5784 & $+1-$ & 41 & $\mathrm{BC}$ & -25.6 & -3.1 & -0.5 & 0.1 & telm & mr [A.glutinosa] \\
\hline 36 & $\mathrm{Hv}$ & 24420 & Hiddensee 32 & 7260 & $+/-$ & 135 & 6154 & $+1-$ & 133 & $\mathrm{BC}$ & -27.2 & -4.0 & -0.8 & 0.2 & telm & wood \\
\hline 37 & $\mathrm{Hv}$ & 24423 & Hiddensee 19 & 7400 & $+1-$ & 55 & 6295 & $+1-$ & 63 & $\mathrm{BC}$ & -29.3 & -6.6 & -0.8 & 0.2 & telm & wood \\
\hline 38 & $\mathrm{Hv}$ & 24421 & Hiddensee 24 & 7475 & $+/-$ & 90 & 6336 & $+/-$ & 81 & $\mathrm{BC}$ & -27.3 & -8.1 & -0.8 & 0.2 & telm & peat, bulk \\
\hline 39 & Bln & 1560 & $\left.\operatorname{Binz}\right|^{* * * *}$ & 7698 & $+/-$ & 46 & 6539 & $+1-$ & 48 & $\mathrm{BC}$ & - & -7.6 & -0.8 & 0.2 & telm & peat, bulk \\
\hline 40 & KIA & 22805 & Wittow Fpl. 97, Gelmer Ort * & 7894 & $+1-$ & 34 & 6757 & $+1-$ & 63 & $\mathrm{BC}$ & - & -2.1 & -0.5 & & terr & wood \\
\hline 41 & $\mathrm{Hv}$ & 24425 & Hiddensee 14 & 8010 & $+1-$ & 195 & 6964 & $+/-$ & 264 & $\mathrm{BC}$ & - & -11.8 & -0.8 & 0.2 & telm & peat, bulk \\
\hline 42 & Bln & 1875 & Binz III **** & 8060 & $+/-$ & 80 & 6987 & $+1-$ & 142 & $\mathrm{BC}$ & - & -9.1 & -0.8 & 0.2 & telm & peat, bulk \\
\hline
\end{tabular}

\footnotetext{
* data provided by Landesamt für Bodendenkmalpflege Mecklenburg-Vorpommern

** data provided by W. Schumacher, Greifswald University

*** data provided by T. Terberger, Greifswald University

**** data provided by H. Kliewe
} 
tude today (fig. 6). However, artificial drainage in the last century has probably led to surface lowering, sediment densification and therefore compaction. It must be argued that the dated samples are today in a lower position than they were primarily. Samples close to the present sl date to ca. 3,000 BC. Thus, all samples of younger age and higher position cannot be used as proper sl index points. Although they might point to a temporary higher sea level, this assumption is not supported by the vegetation analysis and remains speculative. These limitations restrict the potential of the site to some extent to provide correct sl index points. Due to the expected inaccuracy of the data gathered from the Augustenhof site, the sl data set was supplemented with samples derived from nearby archaeological sites onand offshore (LAMPE 2005b, LÜBKE 2005, TERBERGER/SEILER 2005), and with basal peat data known from the surrounding lagoons and the island Hiddensee (BARTHEL 2002). The final data set (tab. 2) contains spatially wider distributed data than those from Wismar (LAMPE ET AL. 2005) and Fischland (this paper). The longer diagonal of the rectangular sampling area, however, does not exceed $40 \mathrm{~km}$ and stretches nearly parallel to the recent uplift isobases (fig. 1). The influence of a wider sample distribution should therefore not contribute to an isostatically-induced larger altitude error of the sl index points. The rsl curve established from these data is shown in fig. $8 \mathrm{C}$.

\section{Wismar study site}

All data used to establish the rsl curve for the Wismar study area have already been published in LAMPE ET AL. (2005). For the comparison with the study areas Fischland and NRügen/Hiddensee and for the determination of the isostatic component, we use the same data without any supplement here (tab. 3). However, we simplified the rsl curve slightly by generalizing its course, avoiding to suggest sl fluctuations where less data are available due to peat degradation. The rsl curve is shown in fig. $8 \mathrm{~A}$.

\section{Discussion}

Sufficient data could be gathered from all study areas to construct rsl curves with relatively narrow error envelopes, which cover the period from today back to 7,000 BC and down to $-13 \mathrm{~m} \mathrm{msl}$ (fig. 8). The error band becomes wider as more sites are considered, as can best be seen from the N-Rügen/Hiddensee curve (fig. $8 \mathrm{C}$ ). For particular time intervals the discrimination between different facies allows a very precise definition of rsl, whereas for other periods data are rare, especially between 2,000 $\mathrm{BC}$ and 1,000 AD, and the sl position remains rather vague. Periods from which radiocarbon data are rare are often related to lower sea level, which caused peat destruction. This conclusion, however, is weakened by the observation that many "intervals of lower sea level" detected in the sediment profiles do not cover the same periods. Here, we abdicate from the identification of uncertain periods of lower sea level and present more generalized rsl envelopes.

In cases where data from different facies exist, they can be checked against each other for reliability. In that way it becomes clear that the samples from Augustenhof (white squares in fig. 8C) have either been influenced by compaction, or have accumulated in a water depth greater than expected, as they plot significantly lower $(0.4$ to $0.7 \mathrm{~m})$ than the well-surveyed underwater finds from the Breeger Bodden (blue circles in fig. 8C) which have the same age. Also, samples from different Körkwitz boreholes having similar ages differ in their heights by about 0.3 to a maximum of $0.7 \mathrm{~m}$ (fig. 8B), pointing to differential upgrowth, auto-compaction, desiccation, decomposition and/or the many other processes which cause undulating matter accumulation and wavy isochrones in the coastal mires.

When comparing the resulting rsl error envelopes from all three study areas, we see that the sl developments show similar trends (fig. 8). At each site the rapid sl rise ended at about 5,500 BC, although at different msl depths. During the subsequent sl development, which was characterized by an overall decrease in rate of sl rise, non-eustatic movements became more important resulting in significantly higher positions of sl index points towards the north of the study area. While at Wismar the sl has been continously rising from lower levels up to the present day on Rügen it reached present msl already about 3,000 to 2,500 BC. Here, rsl was probably temporary higher to some (unknown) extent at 3,000 BC (cf. KLIEWE/JANKE 1982), subsequently experiencing a very slow, long-lasting descent. In all study areas, conspicuous hints were found that at about $1,000 \mathrm{AD}$ the sl started rising more rapidly again (Late Subatlantic transgression, LAMPE/JANKE 2004). This renewed ascent was interrupted during the Little Ice Age, when a prominent black pitchy soil layer was formed in the coastal mires caused by desiccation and peat degradation. Comparable layers were described from many sites along the German and Danish North Sea coast (FreUnD /STREIF 1999, GeHrels ET AL. 2006) and indicate that the Little Ice Age sl variation was a widespread phenomenon. At the southern Baltic coast it was probably the only significant oscillation throughout the last 5,000 years. For other minor fluctuations, such as during the Bronze Age, only vague evidence exists, e.g. in the Körkwitz profile, where a second, but less distinctive black layer exists (LAMPE/JANKE 2004).

Despite the apparent resemblance of the three sl curves, they differ regularly in their age-depth relations, indicating a long-lasting movement of the Earth's crust and implying isostatic movements in the absence of neotectonic movements. In a first step we have investigated the similarity and persistency of the suspected total isostatic movement. The hydro-isostatic subsidence of the coastal area caused by the rising Littorina Sea is included in the total isostatic component, but could not be determined separately. We used a shoreline diagram which relates the msl values of the three rsl curves to each other. The approach rests on the assumption that in a deglacial system and under invariant geological conditions, the uplifting sites reveal a fixed relation when comparing distances from the loading centre and uplift rates: the greater the distance, the smaller the uplift. In this way contemporaneous shorelines at different distances from the loading centre would be located on tilted isochrones running radially from the loading centre to the former ice sheet margin. The gradient of the isolines decreases with decreasing shoreline age. The shoreline diagram approach was used in many ways to investigate differential crustal movements (e. g. Mörner 1976, Donner 1980, KJEmperud 1986). Due 
Tab. 3: Radiocarbon data from the Wismar Bight study area. For details and abbreviations see tab. 1.

Tab. 3: Radiokohlenstoffdatierungen aus dem Untersuchungsgebiet Wismar-Bucht. Für Details und Abkürzungen siehe Tab. 1.

\begin{tabular}{|c|c|c|c|c|c|c|c|c|c|c|c|c|c|c|c|c|}
\hline No & Lab & code & site, sample & & conv. Br & & & $\mathrm{ABC} / \mathrm{A}$ & & & $d^{13} C$ & msl & lowl & uppl & facies & dated material \\
\hline 1 & $\mathrm{KIA}$ & 22874 & Redentin6 & 226 & $+/-$ & 33 & 1721 & $+1-$ & 71 & $\mathrm{AD}$ & -26.1 & 0.0 & -0.5 & 0.1 & telm & indet $\mathrm{mr}$ \\
\hline 2 & KIA & 22873 & Redentin6 & 490 & $+/-$ & 23 & 1423 & $+/-$ & 8 & $\mathrm{AD}$ & -25.9 & -0.3 & -0.5 & 0.1 & telm & indet $\mathrm{mr}$ \\
\hline 3 & $\mathrm{KIA}$ & 22875 & Redentin6 & 535 & $+/-$ & 23 & 1401 & $+/-$ & 16 & $\mathrm{AD}$ & -26.1 & 0.2 & -0.5 & 0.1 & telm & indet mr \\
\hline 4 & $\mathrm{KIA}$ & 19817 & Rustwerder, Salzwiese & 885 & $+1-$ & 25 & 1126 & $+/-$ & 60 & $\mathrm{AD}$ & -23.9 & 0.0 & -0.5 & 0.1 & telm & mr [Betula] \\
\hline 5 & $\mathrm{KIA}$ & 22872 & Redentin6 & 895 & $+/-$ & 33 & 1119 & $+1-$ & 59 & $\mathrm{AD}$ & -24.9 & -0.5 & -0.5 & 0.1 & telm & indet mr \\
\hline 6 & $\mathrm{KIA}$ & 22871 & Redentin6 & 1707 & $+/-$ & 26 & 322 & $+/-$ & 51 & $\mathrm{AD}$ & -27.3 & -0.9 & -0.5 & 0.1 & telm & indet $\mathrm{mr}$ \\
\hline 7 & $\mathrm{KIA}$ & 22876 & Redentin6 & 1810 & $+/-$ & 31 & 192 & $+1-$ & 42 & $\mathrm{AD}$ & -22.5 & -1.0 & -0.5 & 0.1 & telm & seeds \\
\hline 8 & $\mathrm{KIA}$ & 22870 & Redentin6 & 3664 & $+/-$ & 80 & 2058 & $+1-$ & 109 & $\mathrm{BC}$ & -28.2 & -1.9 & -0.5 & 0.1 & telm & indet mr \\
\hline 9 & $\mathrm{KIA}$ & 22869 & Redentin6 & 3918 & $+/-$ & 57 & 2398 & $+/-$ & 79 & $\mathrm{BC}$ & -30.0 & -2.4 & -0.5 & 0.1 & telm & indet $\mathrm{mr}$ \\
\hline 10 & KIA & 22868 & Redentin6 & 4466 & $+/-$ & 37 & 3188 & $+1-$ & 110 & $\mathrm{BC}$ & -28.2 & -2.7 & -0.5 & 0.1 & telm & indet mr \\
\hline 11 & KIA & 22867 & Redentin6 & 4624 & $+/-$ & 45 & 3431 & $+/-$ & 62 & $\mathrm{BC}$ & -27.8 & -3.0 & -0.5 & 0.1 & telm & indet $\mathrm{mr}$ \\
\hline 12 & KIA & 22866 & Redentin6 & 4791 & $+/-$ & 33 & 3587 & $+/-$ & 44 & $\mathrm{BC}$ & -26.4 & -3.2 & -0.5 & 0.1 & telm & seeds \\
\hline 13 & KIA & 19320 & Timmendorf-Nordmole I* & 5256 & $+/-$ & 30 & 4086 & $+1-$ & 75 & $\mathrm{BC}$ & -27.0 & -2.8 & -0.5 & & terr & pole wood \\
\hline 14 & KIA & 16017 & Timmendorf-Nordmole I * & 5280 & $+/-$ & 35 & 4131 & $+/-$ & 75 & $\mathrm{BC}$ & -30.7 & -2.8 & -0.5 & & terr & wooden blade grip \\
\hline 15 & KIA & 20118 & Timmendorf-Nordmole I * & 5293 & $+/-$ & 32 & 4140 & $+1-$ & 69 & $\mathrm{BC}$ & -25.9 & -3.4 & & 0.5 & mar & leister prong \\
\hline 16 & $\mathrm{KIA}$ & 19321 & Timmendorf-Nordmole I * & 5301 & $+/-$ & 27 & 4144 & $+/-$ & 66 & $\mathrm{BC}$ & -27.8 & -2.8 & -0.5 & & terr & pole wood \\
\hline 17 & KIA & 20120 & Timmendorf-Nordmole I * & 5311 & $+/-$ & 31 & 4148 & $+1-$ & 65 & $\mathrm{BC}$ & -27.3 & -3.5 & & 0.5 & mar & leister prong \\
\hline 18 & KIA & 9498 & Timmendorf-Nordmole I * & 5323 & $+/-$ & 35 & 4158 & $+/-$ & 68 & $\mathrm{BC}$ & -31.7 & -3.4 & & 0.5 & mar & leister prong \\
\hline 19 & KIA & 11620 & Timmendorf-Nordmole I * & 5327 & $+/-$ & 39 & 4158 & $+/-$ & 71 & $\mathrm{BC}$ & -28.2 & -3.4 & & 0.5 & mar & logboat fragment \\
\hline 20 & KIA & 19322 & Timmendorf-Nordmole I * & 5338 & $+1-$ & 27 & 4163 & $+1-$ & 69 & $\mathrm{BC}$ & -27.3 & -2.8 & -0.5 & & terr & $\log$ \\
\hline 21 & $\mathrm{KIA}$ & 11618 & Timmendorf-Nordmole I * & 5343 & $+/-$ & 34 & 4168 & $+/-$ & 74 & $\mathrm{BC}$ & -26.2 & -3.4 & & 0.5 & mar & leister prong \\
\hline 22 & KIA & 20123 & Timmendorf-Nordmole I * & 5347 & $+1-$ & 28 & 4170 & $+1-$ & 73 & $\mathrm{BC}$ & -23.6 & -3.4 & & 0.5 & mar & leister prong \\
\hline 23 & KIA & 19319 & Timmendorf-Nordmole I * & 5354 & $+/-$ & 27 & 4179 & $+/-$ & 74 & $\mathrm{BC}$ & -25.3 & -2.8 & -0.5 & & terr & trunk wood \\
\hline 24 & KIA & 12476 & Timmendorf-Nordmole I * & 5388 & $+/-$ & 28 & 4279 & $+1-$ & 36 & $\mathrm{BC}$ & -24.0 & -3.4 & & 0.5 & mar & logboat fragment \\
\hline 25 & KIA & 20124 & Timmendorf-Nordmole I * & 5405 & $+/-$ & 25 & 4290 & $+/-$ & 30 & $\mathrm{BC}$ & -29.1 & -3.5 & & 0.5 & mar & leister prong \\
\hline 26 & $\mathrm{KIA}$ & 12475 & Timmendorf-Nordmole I * & 5418 & $+/-$ & 32 & 4294 & $+/-$ & 31 & $\mathrm{BC}$ & -28.4 & -3.7 & & 0.5 & mar & bow fragment \\
\hline 27 & $\mathrm{KIA}$ & 19318 & Timmendorf-Nordmole I * & 5427 & $+/-$ & 27 & 4299 & $+/-$ & 29 & $\mathrm{BC}$ & -23.6 & -2.8 & -0.5 & & terr & trunk wood \\
\hline 28 & KIA & 16019 & Timmendorf-Nordmole I * & 5443 & $+/-$ & 36 & 4303 & $+/-$ & 32 & $\mathrm{BC}$ & -28.9 & -2.8 & -0.5 & & terr & wooden bowl \\
\hline 29 & KIA & 9499 & Timmendorf-Nordmole | * & 5456 & $+/-$ & 37 & 4308 & $+1-$ & 34 & $\mathrm{BC}$ & -22.8 & -3.5 & & 0.5 & mar & Cervus bone \\
\hline 30 & $\mathrm{KIA}$ & 20126 & Timmendorf-Nordmole I * & 5478 & $+/-$ & 22 & 4338 & $+/-$ & 12 & $\mathrm{BC}$ & -26.7 & -3.6 & & 0.5 & mar & leister prong \\
\hline 31 & KIA & 11619 & Timmendorf-Nordmole I * & 5505 & $+/-$ & 37 & 4378 & $+/-$ & 39 & $\mathrm{BC}$ & -27.6 & -3.6 & & 0.5 & mar & leister prong \\
\hline 32 & KIA & 22798 & Trollegrund * & 5725 & $+/-$ & 36 & 4583 & $+/-$ & 57 & $\mathrm{BC}$ & -30.1 & -1.3 & -0.5 & & terr & tree stump \\
\hline 33 & KIA & 20122 & Timmendorf-Nordmole I * & 5785 & $+/-$ & 30 & 4641 & $+1-$ & 45 & $\mathrm{BC}$ & -30.2 & -3.9 & -0.5 & & terr & $\mathrm{mr}$ [Corylus] \\
\hline 34 & $\mathrm{KIA}$ & 22797 & Trollegrund * & 5870 & $+1-$ & 28 & 4749 & $+1-$ & 29 & $\mathrm{BC}$ & -24.4 & -1.5 & -0.5 & & terr & tree stump \\
\hline 35 & KIA & 20431 & Timmendorf-Nordmole II * & 5966 & $+/-$ & 42 & 4859 & $+1-$ & 55 & $\mathrm{BC}$ & -25.0 & -5.0 & & 0.5 & mar & wooden post \\
\hline 36 & KIA & 20427 & Timmendorf-Nordmole II * & 6009 & $+/-$ & 36 & 4904 & $+/-$ & 48 & $\mathrm{BC}$ & -30.1 & -5.0 & & 0.5 & mar & fish trap \\
\hline 37 & KIA & 20127 & Timmendorf-Nordmole I * & 6035 & $+1-$ & 24 & 4937 & $+/-$ & 40 & $\mathrm{BC}$ & -28.5 & -3.9 & -0.5 & & terr & $\log$ \\
\hline 38 & $\mathrm{KIA}$ & 20428 & Timmendorf-Nordmole II * & 6054 & $+/-$ & 31 & 4960 & $+/-$ & 41 & $\mathrm{BC}$ & -28.0 & -5.0 & & 0.5 & mar & fish trap \\
\hline 39 & KIA & 20432 & Timmendorf-Nordmole II * & 6072 & $+1-$ & 32 & 4987 & $+/-$ & 39 & $\mathrm{BC}$ & -28.8 & -5.0 & & 0.5 & mar & wooden post \\
\hline 40 & KIA & 24231 & Timmendorf-Nordmole $\|$ * & 6088 & $+/-$ & 33 & 5007 & $+1-$ & 43 & $\mathrm{BC}$ & -28.2 & -5.4 & & 0.5 & mar & leister prong \\
\hline 41 & KIA & 24230 & Timmendorf-Nordmole II * & 6108 & $+/-$ & 35 & 5077 & $+/-$ & 84 & $\mathrm{BC}$ & -33.3 & -5.2 & & 0.5 & mar & leister prong \\
\hline 42 & $\mathrm{KIA}$ & 20429 & Timmendorf-Nordmole II * & 6110 & $+1-$ & 30 & 5079 & $+/-$ & 78 & $\mathrm{BC}$ & -27.6 & -5.0 & & 0.5 & mar & wooden post \\
\hline 43 & $\mathrm{KIA}$ & 24077 & Timmendorf-Nordmole II * & 6136 & $+1-$ & 35 & 5107 & $+1-$ & 77 & $\mathrm{BC}$ & -22.2 & -5.2 & & 0.5 & mar & Capreolus bone \\
\hline 44 & $\mathrm{KIA}$ & 20430 & Timmendorf-Nordmole II * & 6137 & $+/-$ & 38 & 5106 & $+/-$ & 78 & $\mathrm{BC}$ & -27.3 & -5.0 & & 0.5 & mar & wooden post \\
\hline 45 & KIA & 22796 & Trollegrund * & 6243 & $+1-$ & 34 & 5218 & $+1-$ & 68 & $\mathrm{BC}$ & -26.9 & -3.1 & -0.5 & & terr & tree stump \\
\hline 46 & $\mathrm{KIA}$ & 22800 & Timmendorf-Nordmole II * & 6319 & $+/-$ & 43 & 5295 & $+1-$ & 50 & $\mathrm{BC}$ & -26.8 & -5.0 & -0.5 & & terr & tree stump \\
\hline 47 & $\mathrm{KIA}$ & 22799 & Timmendorf-Nordmole II * & 6532 & $+1-$ & 44 & 5506 & $+1-$ & 29 & $\mathrm{BC}$ & -28.8 & -5.0 & -0.5 & & terr & tree stump \\
\hline 48 & KIA & 19819 & Rustwerder P5B1 & 6775 & $+1-$ & 35 & 5681 & $+1-$ & 27 & $\mathrm{BC}$ & -25.0 & -7.3 & -0.5 & 0.1 & telm & $\mathrm{mr}$ [Betula] \\
\hline 49 & $\mathrm{KIA}$ & 22792 & Trollegrund * & 6842 & $+/-$ & 27 & 5719 & $+/-$ & 22 & $\mathrm{BC}$ & -25.6 & -5.1 & -0.5 & & terr & tree stump \\
\hline 50 & $\mathrm{KIA}$ & 22793 & Trollegrund * & 6856 & $+/-$ & 33 & 5742 & $+1-$ & 30 & $\mathrm{BC}$ & -23.0 & -5.1 & -0.5 & & terr & tree stump \\
\hline 51 & KIA & 18210 & Jäckelgrund-Strand * & 6882 & $+1-$ & 33 & 5772 & $+/-$ & 34 & $\mathrm{BC}$ & -28.0 & -7.8 & -0.5 & & terr & tree stump \\
\hline 52 & $\mathrm{KIA}$ & 19242 & Jäckelgrund-Orth * & 6888 & $+/-$ & 35 & 5779 & $+/-$ & 38 & $\mathrm{BC}$ & -21.5 & -6.6 & -0.5 & & terr & tree stump \\
\hline 53 & KIA & 19243 & Jäckelgrund-Orth * & 6916 & $+1-$ & 35 & 5799 & $+1-$ & 41 & $\mathrm{BC}$ & -24.3 & -7.2 & -0.5 & & terr & tree stump \\
\hline 54 & $\mathrm{KIA}$ & 18209 & Jäckelgrund-Orth * & 6969 & $+/-$ & 33 & 5851 & $+1-$ & 44 & $\mathrm{BC}$ & -24.4 & -7.2 & -0.5 & & terr & tree stump \\
\hline 55 & $\mathrm{KIA}$ & 24227 & Trollegrund * & 7010 & $+/-$ & 34 & 5915 & $+/-$ & 51 & $\mathrm{BC}$ & -26.5 & -8.2 & -0.5 & & terr & tree stump \\
\hline 56 & KIA & 19241 & Jäckelgrund-Orth * & 7014 & $+/-$ & 36 & 5917 & $+/-$ & 50 & $\mathrm{BC}$ & -22.9 & -6.7 & -0.5 & & terr & tree stump \\
\hline 57 & $\mathrm{KIA}$ & 19240 & Jäckelgrund-Orth * & 7022 & $+/-$ & 44 & 5918 & $+/-$ & 53 & $\mathrm{BC}$ & -24.1 & -6.5 & -0.5 & & terr & tree stump \\
\hline 58 & $\mathrm{KIA}$ & 19323 & Jäckelgrund-Furt * & 7022 & $+/-$ & 33 & 5927 & $+/-$ & 43 & $\mathrm{BC}$ & -25.2 & -7.9 & -0.5 & & terr & tree stump \\
\hline
\end{tabular}




\begin{tabular}{|c|c|c|c|c|c|c|c|c|c|c|c|c|c|c|c|c|}
\hline 59 & KIA & 22795 & Trollegrund * & 7032 & $+/-$ & 35 & 5934 & $+1-$ & 40 & $\mathrm{BC}$ & -24.2 & -5.7 & -0.5 & & terr & tree stump \\
\hline 60 & KIA & 22804 & Jäckelgrund-Orth * & 7090 & $+/-$ & 32 & 5968 & $+1-$ & 37 & $\mathrm{BC}$ & -27.1 & -8.5 & -0.5 & & terr & tree stump \\
\hline 61 & KIA & 24228 & Trollegrund * & 7103 & $+/-$ & 37 & 5976 & $+1-$ & 40 & $\mathrm{BC}$ & -26.1 & -8.2 & -0.5 & & terr & tree stump \\
\hline 62 & KIA & 23941 & Jäkelberg-Huk* & 7108 & $+1-$ & 37 & 5979 & $+1-$ & 41 & $\mathrm{BC}$ & -18.1 & -8.5 & -0.5 & & terr & Esox bone \\
\hline 63 & KIA & 22791 & Trollegrund * & 7133 & $+/-$ & 50 & 6001 & $+/-$ & 48 & $\mathrm{BC}$ & -25.7 & -5.2 & -0.5 & & terr & tree stump \\
\hline 64 & KIA & 20441 & Trollegrund * & 7146 & $+1-$ & 33 & 6027 & $+1-$ & 22 & $\mathrm{BC}$ & -27.4 & -8.8 & -0.5 & & terr & tree stump \\
\hline 65 & KIA & 20438 & Trollegrund * & 7150 & $+1-$ & 31 & 6030 & $+1-$ & 20 & $\mathrm{BC}$ & -24.6 & -8.8 & -0.5 & & terr & tree stump \\
\hline 66 & KIA & 22803 & Jäckelgrund-Orth * & 7154 & $+/-$ & 41 & 6031 & $+1-$ & 25 & $\mathrm{BC}$ & -26.5 & -8.2 & -0.5 & & terr & tree stump \\
\hline 67 & KIA & 22794 & Trollegrund * & 7158 & $+1-$ & 40 & 6033 & $+1-$ & 24 & $\mathrm{BC}$ & -26.4 & -5.1 & -0.5 & & terr & tree stump \\
\hline 68 & KIA & 24226 & Trollegrund * & 7165 & $+/-$ & 39 & 6037 & $+/-$ & 23 & $\mathrm{BC}$ & -27.1 & -8.2 & -0.5 & & terr & tree stump \\
\hline 69 & KIA & 20439 & Trollegrund * & 7197 & $+1-$ & 33 & 6053 & $+1-$ & 22 & $\mathrm{BC}$ & -25.4 & -8.8 & -0.5 & & terr & tree stump \\
\hline 70 & KIA & 24229 & Trollegrund * & 7203 & $+/-$ & 29 & 6055 & $+1-$ & 21 & $\mathrm{BC}$ & -25.7 & -8.2 & -0.5 & & terr & tree stump \\
\hline 71 & KIA & 20443 & Trollegrund * & 7224 & $+1-$ & 32 & 6107 & $+1-$ & 56 & $\mathrm{BC}$ & -27.9 & -8.5 & -0.5 & & terr & tree stump \\
\hline 72 & KIA & 20442 & Trollegrund * & 7229 & $+1-$ & 38 & 6116 & $+/-$ & 62 & $\mathrm{BC}$ & -26.3 & -8.5 & -0.5 & & terr & tree stump \\
\hline 73 & KIA & 23940 & Jäkelberg-Huk * & 7239 & $+1-$ & 37 & 6126 & $+/-$ & 59 & $\mathrm{BC}$ & -20.7 & -8.5 & -0.5 & & terr & mammalia bone \\
\hline 74 & KIA & 24225 & Trollegrund * & 7247 & $+1-$ & 32 & 6109 & $+1-$ & 62 & $\mathrm{BC}$ & -26.6 & -8.2 & -0.5 & & terr & tree stump \\
\hline 75 & KIA & 26007 & Ellenbogen 5/10 & 7285 & $+/-$ & 35 & 6151 & $+1-$ & 50 & $\mathrm{BC}$ & -26.0 & -11.0 & -0.5 & 0.1 & telm & basal peat, bulk \\
\hline 76 & KIA & 20440 & Trollegrund * & 7290 & $+1-$ & 32 & 6143 & $+1-$ & 54 & $\mathrm{BC}$ & -25.8 & -8.8 & -0.5 & & terr & tree stump \\
\hline 77 & KIA & 23701 & Jäkelberg-Huk * & 7387 & $+1-$ & 42 & 6289 & $+/-$ & 56 & $\mathrm{BC}$ & -15.5 & -8.5 & -0.5 & & terr & Esox bone \\
\hline 78 & $\mathrm{KIA}$ & 24223 & Großes Tief-Ostufer * & 7395 & $+1-$ & 45 & 6294 & $+1-$ & 57 & $\mathrm{BC}$ & -27.8 & -9.8 & -0.5 & & terr & tree stump \\
\hline 79 & KIA & 23699 & Jäkelberg-Huk * & 7416 & $+/-$ & 43 & 6308 & $+1-$ & 53 & $\mathrm{BC}$ & -22.5 & -8.5 & -0.5 & & terr & Cervus bone \\
\hline 80 & KIA & 24224 & Großes Tief-Ostufer * & 7440 & $+/-$ & 35 & 6320 & $+/-$ & 50 & $\mathrm{BC}$ & -28.0 & -9.8 & -0.5 & & terr & tree stump \\
\hline 81 & KIA & 24222 & Großes Tief-Ostufer * & 7457 & $+/-$ & 38 & 6330 & $+/-$ & 55 & $\mathrm{BC}$ & -27.5 & -10.9 & -0.5 & & terr & tree stump \\
\hline 82 & KIA & 20444 & Trollegrund * & 7464 & $+/-$ & 46 & 6335 & $+/-$ & 59 & $\mathrm{BC}$ & -27.6 & -7.7 & -0.5 & & terr & tree stump \\
\hline 83 & $\mathrm{KIA}$ & 23700 & Jäkelberg-Huk* & 7469 & $+/-$ & 39 & 6337 & $+/-$ & 58 & $\mathrm{BC}$ & -20.5 & -8.5 & -0.5 & & terr & Capreolus bone \\
\hline 84 & KIA & 22790 & Trollegrund * & 7741 & $+/-$ & 38 & 6568 & $+1-$ & 48 & $\mathrm{BC}$ & -26.0 & -12.8 & -0.5 & & terr & tree stump \\
\hline 85 & KIA & 22789 & Trollegrund * & 7788 & $+/-$ & 38 & 6615 & $+/-$ & 35 & $\mathrm{BC}$ & -28.6 & -12.7 & -0.5 & & terr & tree stump \\
\hline 86 & KIA & 22788 & Trollegrund * & 7919 & $+1-$ & 37 & 6838 & $+1-$ & 118 & $\mathrm{BC}$ & -28.0 & -12.7 & -0.5 & & terr & tree stump \\
\hline
\end{tabular}

* data provided by Landesamt für Bodendenkmalpflege Mecklenburg-Vorpommern

to the great distance to the loading centre in N-Sweden at about $64^{\circ} \mathrm{N} / 22^{\circ} \mathrm{E}$, here, only the differential radial distances between the centres of the study areas will be considered. Taking $0 \mathrm{~km}$ for $\mathrm{N}$-Rügen/Hiddensee, the differential radial distance to the Fischland study area amounts to $55 \mathrm{~km}$ and to the Wismar sites to $115 \mathrm{~km}$. Fig. 9 depicts the shoreline diagram which shows that during the past 8,000 years the movement of the three sites always followed the same trend suggesting and confirming that differential block-like tectonic movements between the sites occurred only to a minor extent, if at all.

In a second step we have tried to estimate the amount of absolute isostatic uplift experienced at the different sites. The estimation of the isostatic component of rsl movement is possible using geophysical models (STEFFEN et al. 2006), which require a knowledge of many parameters of the Earth's interior and the (de-)glaciation history. An alternative way is to compare the relative curves with a curve from a nearby area believed to be tectonically and isostatically stable. As the German North Sea coast was recently identified as a subsiding region (VINK et al. 2007), the nearest area suitable for comparison is the Belgian North Sea coast, which is situated on the margin of the Brabant-London Massif and has, therefore, experienced greater crustal stability. Of all available NW European rsl curves, it may have been least affected by isostatic movements, although there is no evidence that isostatics played no role here.

The Belgian rsl curve published by Denys/Baeteman (1995) is given as an envelope depicting the maximal level of lowest local mean high water (MHW = upper msl limit).
Originally related to T.A.W. (Belgian Ordnance Datum), KIDEN et al. (2002) recalculated the rsl values to N.A.P. (Normaal Amsterdams Peil, ca. $0.1 \mathrm{~m}$ above msl) and used the curve to estimate differential isostatic and tectonic land movements along the Belgian-Dutch North Sea coast. The msl curve, however, could lie as much as $2 \mathrm{~m}$ lower than the MHW curve due to the tidal amplitude. VINK et al. (2007) made an attempt to estimate 'absolute' msl from the original data of Denys/Baeteman (1995) depending on the indicative meaning of the sl index points. Using this method, the Belgian "absolute" msl curve comes to lie somewhat lower than that shown in fig. 10. Due to limited data, it covers only a time span from about 9,500 to 5,500 cal BP. An additional problem is that the tidal ranges along the Belgian coast have most likely changed in the past, in relation to the flooding of the North Sea Basin and the opening of the French Channel. All these points make the comparison of the Baltic Sea rsl curves with the upper limit of msl Belgian coast problematic. Despite the uncertain geoidal change and the potential changes of past tidal amplitude on former msl, a comparison with the rsl curves from the NE German Baltic coast provides probably a better estimation of the range of isostatic movement of the study areas than a comparison with any other rsl curve of NW Europe.

Due to the restricted data available from the south Baltic coastal area, the comparison is restricted to the period since 7,000 BC (fig. 10). Obviously, from 7,000 BC until about 3,500 BC, the NE German curves all plot higher than the Belgian curve. Since then, the Wismar curve tends to run lower, although the envelopes do overlap and the difference may, 

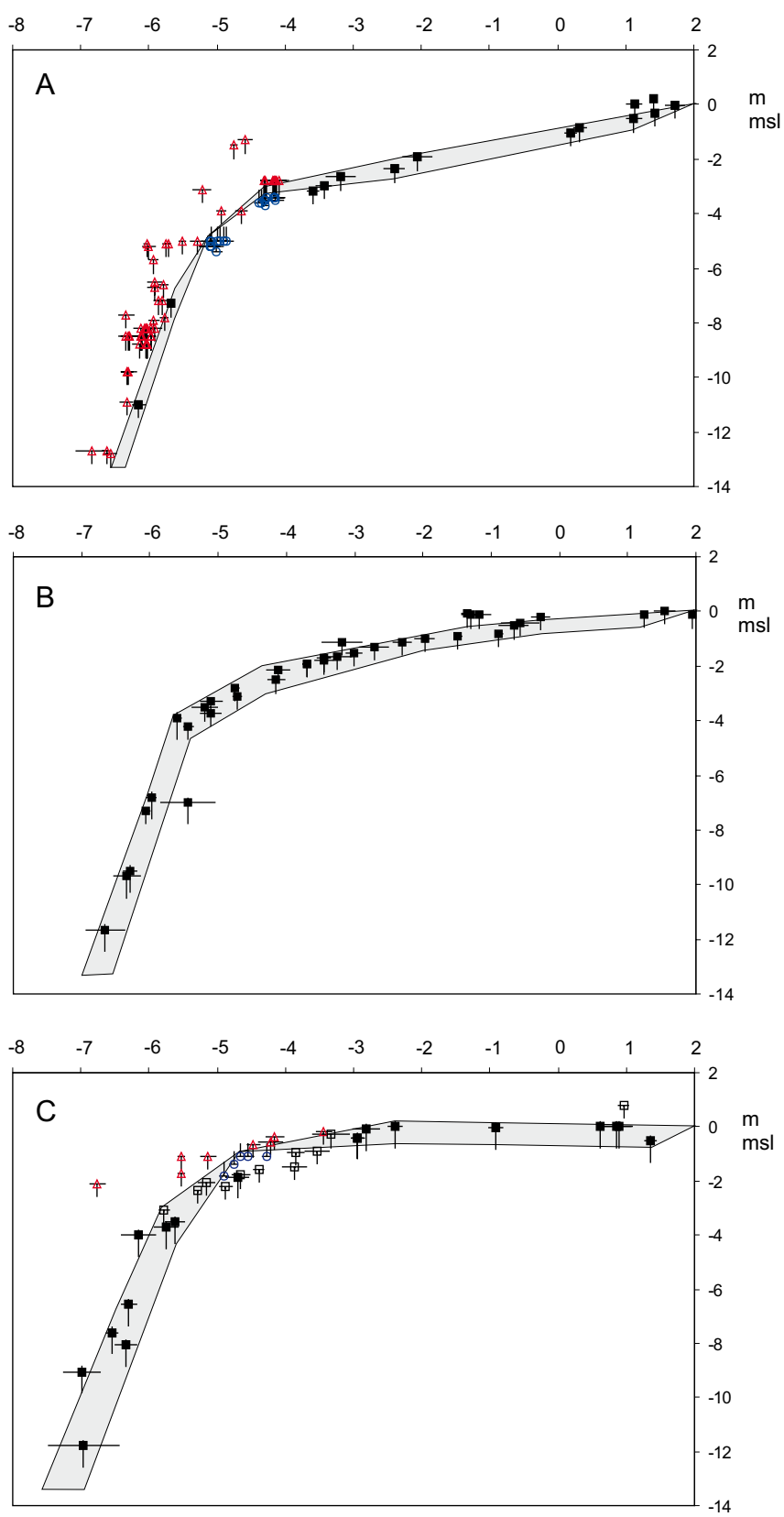

Fig. 8: Rsl curves from A) Wismar (upper diagram, Lampe et al. 2005), B) Fischland (centre diagram) and C) N-Rügen/Hiddensee (lower diagram). Red triangles point to data from terrestrial deposits, blue circles to archaeological finds from marine nearshore deposits and black squares represent data from telmatic environments. White squares in the lower diagram $(C)$ indicate the data from the Augustenhof site, which were influenced by compaction or where peat growth was independent from sl. Horizontal bars represent twofold standard deviation $(2 \sigma)$, vertical bars indicate estimated vertical error of sea-level position. For sample details see tab. 1-3. The error envelopes intentionally drawn according to time-depth-error bars indicate the interval in which the sl was most probably located.

Abb. 8: Relative Meeresspiegelkurven für A) Wismar (oberes Diagramm, Lampe et al. 2005), B) Fischland (mittleres Diagramm) und C) N-Rügen/ Hiddensee (unteres Diagramm). Rote Dreiecke repräsentieren Daten aus terrestrischen Ablagerungen, blaue Kreise verweisen auf archäologische Funde aus flachmarinen Sedimenten und schwarze Quadrate stehen für Daten aus telmatischen Ablagerungen. Weiße Quadrate im unteren Diagramm (C) verweisen auf Daten von Augustenhof, für die ein Kompaktionseinfluss oder ein vom Meeresspiegel unabhängiges Torfwachstum angenommen werden muss. Die horizontalen Balken an den Symbolen repräsentieren die zweifa-

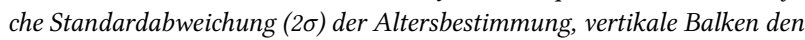
geschätzten Höhenfehler der Meeresspiegelposition. Für Detailangaben zu den Proben siehe Tab. 1-3. Die entsprechend der Zeit-Höhen-Fehler der Daten angenommene Hüllkurve gibt das Intervall wieder, in dem der Meeresspiegel sich höchstwahrscheinlich befunden hat. therefore, be insignificant. The Fischland curve overlaps the upper part of the Belgian curve, but with decreasing age takes on the same height interval. The N-Rügen/Hiddensee curve clearly plots above all other curves. Assuming a correctness of all curves fig. 10 shows that the isostatic movement relative to the Belgian coast in the areas around Wismar and Fischland has presently more or less ceased but most probably continues on Rügen. For the Wismar area, a slight subsidence might be speculated, also suspected by LAMBECK et al. (1998). Although the Belgian curve ends at ca. $500 \mathrm{AD}$, we can extrapolate the long-term trend until today, as reconstructed former movements coincide adequately with recent tide gauge measurements. Using the age/height differences between envelope mid-points allows the determination of smoothing functions, which make the movement tendencies clearer (fig. 11). The accuracy of this visualization, however, is not as high as it might easily be suggested by these simple lines. Fluctuations caused by sea level and/or local crustal movements within the enveloped areas have to be considered, even if they cannot be detected accurately.

\section{Summary and conclusions}

Rsl curves established from regionally distributed data might be influenced by differential isostatic movements at the sites sampled. The construction of rsl curves for small study areas may circumvent this source of uncertainty but has to deal with the problem of less sites providing reliable sl index points. In the uppermost several metres below present-day msl basal peat has very rarely developed. We have therefore used coastal mires for sampling, which grew in association with the slowly rising sea level in locations sheltered from strong waves and currents, i. e. particularly at lagoonal coast sections. It is, however, not clear to what extent the mire profiles underwent (auto-)compaction, so other sl indicators are always required for independent cross-check and evaluation.

The three new rsl curves established along a gradient of recent rsl change along the NE German (Baltic) coast

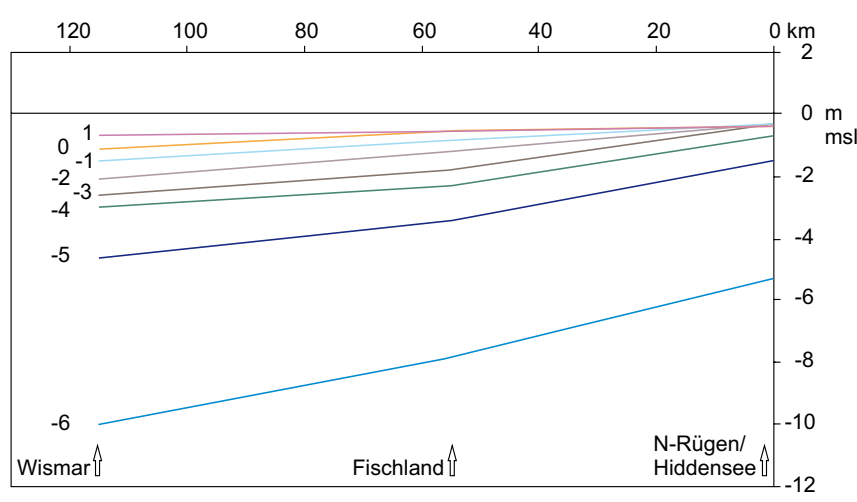

Fig. 9: Shoreline diagram for the three study areas using the differential radial distances from the loading centre, with $\mathrm{N}$-Rügen/Hiddensee at $0 \mathrm{~km}$, Fischland at $55 \mathrm{~km}$ and Wismar at $115 \mathrm{~km}$. The lines are isochrones revealing the position of sea level at the three sites at given ages (in ka AD).

Abb. 9: Diagramm der Uferlinienverschiebung für die drei Untersuchungsgebiete entsprechend der Differenzen ihrer radialen Distanz vom eisisostatischen Belastungszentrum, mit N-Rügen/Hiddensee bei $0 \mathrm{~km}$, Fischland bei $55 \mathrm{~km}$ und Wismar bei $115 \mathrm{~km}$. Die Linien stellen Isochronen dar, die die heutige Höhenposition der vormaligen Uferlinie (Alter angegeben in 1000 Jahren n. Chr.) in den drei Untersuchungsgebieten wiedergeben. 


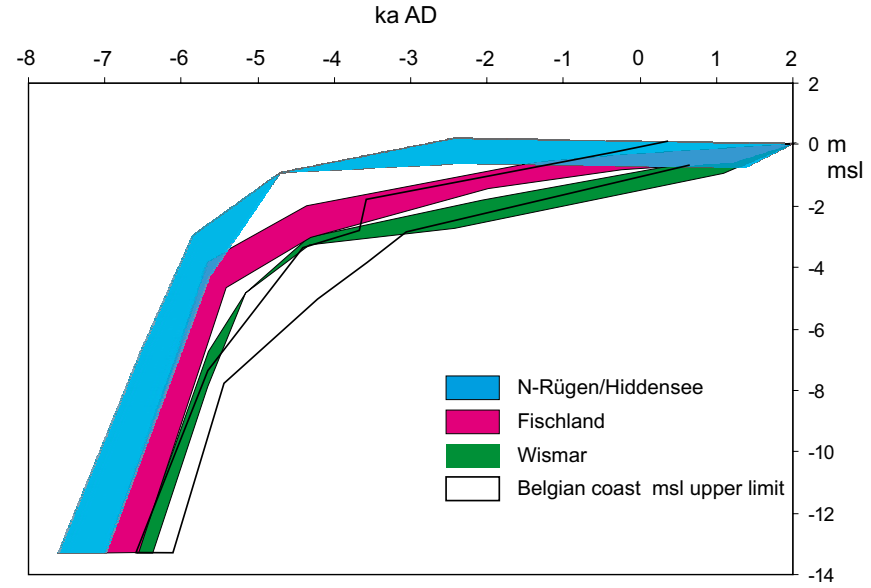

Fig. 10: Rsl curves of Wismar, Fischland and N-Rügen/Hiddensee in comparison to the rsl error band of the Belgian coast (DENYS/BAETEMAN 1995, KIDEN ET AL. 2002).

Abb. 10: Die relativen Meeresspiegelkurven der Untersuchungsgebiete Wismar, Fischland und N-Rügen/Hiddensee im Vergleich mit der Hüllkurve des relativen Meeresspiegels an der belgischen Küste (DENYS/BAETEMAN 1995, KIDEN ET AL. 2002).

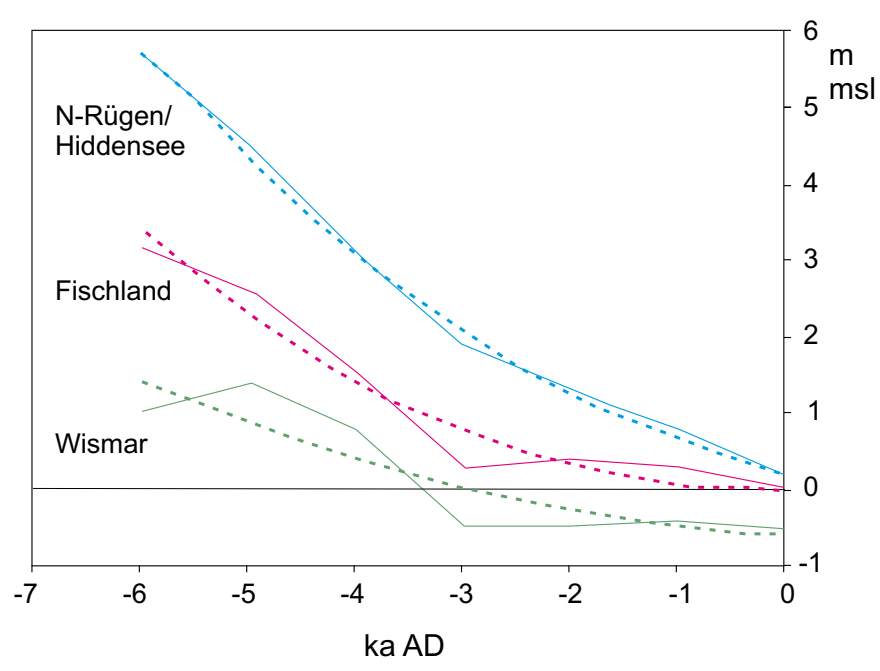

Fig. 11: Isostatic (or, more correct, non-eustatic) movements of the three study areas calculated by subtracting the error band mid-points of the Belgian rsl curve from those of the rsl curves of the study areas. Smoothing functions suggest a permanent decrease of the crustal movement rate at all sites with a transition to subsidence at Wismar (green), stable conditions at Fischland (red) and slight upheaval at Rügen (blue). Note that the time axis ends at $O A D$ due to the period covered by the Belgian coast curve.

Abb. 11: Isostatische (oder, korrekter, nicht-eustatische) Bewegungen der drei Untersuchungsgebiete, berechnet durch Subtraktion der HüllkurvenMittelpunkte der belgischen relativen Meeressspiegelkurve von denen der relativen Meeressspiegelkurven der Untersuchungsgebiete. Die zugehörigen Ausgleichskurven deuten auf eine permanente Abnahme der Krustenbewegungsrate in den Untersuchungsgebieten hin mit einem Übergang zur Senkung in Wismar (grün), stabilen Bedingungen am Fischland (rot) und noch leichter Hebung auf Rügen (blau). Entsprechend dem von der belgischen Kurve abgedeckten Zeitintervall endet die Zeitachse bei 0 n. Chr.!

and in study areas of limited geographic extent all base on a coastal mire profile providing the main course of rsl rise during the past $6 \mathrm{ka}$. Basal peat samples were used to extend the curves to greater depth and age or - together with archaeological finds and/or drowned tree stumps - for completion and reliability tests. From these curves some important conclusions can be drawn:
1. Depending on the determined error range in age and vertical height of the samples, rsl curves were constructed as error bands. Due to the dispersion in both factors the mean accuracy of a sl index point is no better than $\pm 1 \mathrm{~m}$ and \pm 200 a, i.e. small-scale sea-level fluctuations can hardly be detected. Dispersion is not apparent in single peat profiles, although age inversions do sometimes occur. However, data from different profiles located very close to each other do show differences resulting from factors like (auto-)compaction, material redeposition, differential peat accumulation or erosion and these cannot be avoided. The only small-scale sl fluctuation detected in many single profiles is related to the Little Ice Age, but the extent of the water table fall is still unknown.

2. The three curves are very similar in form, with a steep sl ascent ending at about 5,500 BC. After a transition period until about 4,500 $\mathrm{BC}$ with decreasing rates of sl rise, the subsequent rates almost stabilised, albeit to a different extent. While in Wismar the sl continued to rise, it stabilised on Rügen or even fell.

3. A close comparison of the three curves shows that they differ from each other regularly, with deviations becoming smaller with decreasing age. A shoreline diagram indicates that no significant tectonic events disturbed the relative movements between the three study areas. Except for some minor activities, neither the fault systems in the subsoil nor the Permian salt deposits have apparently influenced the areas investigated.

4. Consequences of a sl retardation or fall should occur most pronouncedly on Rügen, where the higher rate of isostatic rise would amplify them. Vice versa, consequences of a sl rise would be amplified in Wismar because they are backed by a low or even negative isostatic movement. The most suitable sites to determine true sl fluctuations are sediment sequences located near to the isostatic null line, e.g. in the vicinity of Fischland, Greifswald and central Usedom (fig. 1).

5. The comparison with a rsl curve from the Belgian coast, which is believed to be tectonically and isostatically more stable and influenced predominantly by the eustatic sl rise, allows an estimation of the isostatic component along the Baltic coast relative to the Belgian coast. The smoothed differences between the Belgian and Baltic rsl curves show a non-linear decrease during the past $9 \mathrm{ka}$. In the Wismar area, isostatic rise ended at about $3 \mathrm{ka} \mathrm{BC}$ and inverted to slow subsidence (fig. 11). In the Fischland area, isostatic movement ceased ca. 1 to $0 \mathrm{ka} B C$ and was replaced by a rather stable or indifferent behaviour. For the N-Rügen/ Hiddensee study area, an ongoing slow uplift is still evident. Further improvements in all rsl curves may slightly change these estimations. For instance, changes regarding the reliability of the error bands, the indicative meaning of the sl index points or the past Belgian tidal amplitude may alter the course of the error bands and though the relation to each other. Therefore, we cannot finally state whether the Wismar area experiences a subsidence or the same movement when compared with the Belgian coast. For such a conclusion further evidence is needed. The reconstructed movement trends, however, fit well with the movements deduced from recent marine tide gauge measurements. In turn, the past motions allow an extrapolation to the future. We conclude that isostatic movements will 
still have a significant influence on future rsl rise rates and its related coastal morphodynamics.

\section{Acknowledgement}

This study was possible due to the financial support provided by the Deutsche Forschungsgemeinschaft, which is gratefully acknowledged (FO 488/1). We thank all members of the SINCOS Research Group for valuable data and discussions, and students and staff from Greifswald University for their help in the field and laboratories. The paper benefits from very helpful recommendations and corrections of two anonymous reviewers which are gratefully acknowledged.

\section{References}

Allen, J. R. L. (1999): Geological impacts on coastal wetland landscapes: some general effects of sediment autocompaction in the Holocene of northwest Europe. - Holocene 9(1), 1-12.

BANKwitz, P. (1971): Geologische Auswertung von geodätisch ermittelten rezenten Krustenbewegungen im Gebiet der DDR. - Petermanns Geographische Mitteilungen 115(2), 130-140.

Barthel, A. (2002): Aufbau und Entwicklung der holozänen Sedimente der Insel Hiddensee und deren Modellierung mit geostatistischen Methoden. - Thesis, Universität Greifswald, Institut für Geographie und Geologie, 109 pp.

BeHre, K.-E. (2003): Eine neue Meeresspiegelkurve für die südliche Nordsee. - Probleme der Küstenforschung im südlichen Nordseegebiet 28, 9-63.

Benkert, D., Fukarek, F., Korsch, H. (1996): Verbreitungsatlas der Farnund Blütenpflanzen Ostdeutschlands. - Jena: Fischer, 615 pp.

Bennike, O., Jensen, J. B. (1998): Late- and postglacial shore level changes in the south-western Baltic Sea. - Bulletin of the Geological Society of Denmark 45, 27-38.

Bennike, O., Jensen, J. B., Lemke, W., Kuijpers, A., Lomholt, S. (2004): Late- and postglacial history of the Great Belt, Denmark. - Boreas $33,18-33$.

BJöRK, S. (1995): A review of the history of the Baltic Sea 13.0-8.0 ka BP. Quaternary International 27, 19-40.

Bjornsen, M., Clemmensen, L. B., Murray, A., Pedersen, K. (2008): New evidence of the Littorina transgressions in the Kattegat: Optically Stimulated Luminescence dating of a beach ridge system on Anholt, Denmark. - Boreas 37(1), 157-168.

Christensen, Ch. (1995): The littorina transgression in Denmark. - In: Fischer, A. (Ed.), Man and sea in the Mesolithic, Oxbow Books, Oxford, 15-22.

Christensen, Ch., Fischer, A., Mathiasen, D. R. (1997): The great sea rise in the Storebaelt. - In: Pedersen, L., Fischer, A., Aaby, B. (Eds.): The Danish Storebaelt since the Ice Age. A/S Storebaeltforbindelsen, 116-121.

Danzeglocke, U., JöRis, O., Weninger, B. (2007) CalPal-2007online. http://www.calpal-online.de/ accessed 2007/10.

Denys, L., BAEteman, C. (1995): Holocene evolution of relative sea leve and local mean high water spring tides in Belgium - a first assessment. - Marine Geology 124, 1-19.

Dietrich, R., Liebsch, G. (2000): Zur Variabilität des Meeresspiegels an der Küste von Mecklenburg-Vorpommern. - Zeitschrift für Geologische Wissenschaften 28(6), 615-624.

Donner, J. J. (1980): The determination and dating of synchronous Late Quaternary shorelines in Fennoscandia. - In: MörnER, N.-A. (Ed.): Eart Rheology, Isostasy and Eustacy. Wiley, New York, 285-293.

Duphorn, K. (1979): The Federal Republic of Germany. - In: Gudelis, V., KönIGsson, L.-K. (Eds.): The Quarternary history of the Baltic. Uppsala, 195-206.

EкMAN, M. (1996): A consistent map of the postglacial uplift of Fennoscandia. - Terra Nova 8(2), 158-165.

ElLENBERG, J. (1988): Rezente vertikale Erdkrustenbewegung als geologischer Prozeß. - PhD thesis, Akademie der Wissenschaften der DDR, Klasse Geo- und Kosmoswissenschaften, Potsdam, 141 pp.

ENDTMANN, E. (2005): Erste Ergebnisse der neuen paläobotanischen Un- tersuchungen am mesolithischen Fundplatz von Lietzow-Buddelin auf Rügen. - Bodendenkmalpflege in Mecklenburg-Vorpommern, Jahrbuch 2004, 52, 197-209.

Endtmann, E. (2006): Häufige botanische Makroreste in Ablagerungen des südlichen Ostseeraumes und das Küstenüberflutungsmoor Körkwitz nahe Ribnitz-Damgarten (Saaler Bodden). - Meyniana 58, 57-74.

Freund, H., Streif, H. (1999): Natürliche Pegelmarken für Meeresspiegelschwankungen der letzten 2000 Jahre im Bereich der Insel Juist. - Petermanns Geographische Mitteilungen 143(Pilotheft 2000), 34-45.

Garetsky, R. G., Ludwig, A. O., Schwab, G., Stackebrandt, W. (2001): Neogeodynamics of the Baltic Sea depression and adjacent areas Results of IGCP project 346. - Brandenburgische Geowissenschaftliche Beiträge 8(1), 47 pp.

Gehrels, W. R., Szkornik, K., Bartholdy, J., Kirby, J. R., Bradley, S. L., Marshall, W. A., Heinemeier, J., Pedersen, J. B. T. (2006): Late Holocene sea-level changes and isostasy in western Denmark. - Quaternary Research 66(2), 288-302.

Geyh, M.A. (1983): Physikalische und chemische Datierungsmethoden in der Quartärforschung. - Clausthaler Tektonische Hefte 19, 163 pp.

Gramsch, B. (1978): Die Lietzow-Kultur Rügens und ihre Beziehungen zur Ostseegeschichte. - Petermanns Geographische Mitteilungen 122(3), $155-164$.

HÜNICKE, B. (2008): Atmospheric forcing of decadal Baltic Sea level variability in the last 200 years: A statistical analysis. - PhD Thesis, Univ. Hamburg, $130 \mathrm{pp}$.

HyväRInEN, H. (2000): The history of the Baltic. - Lundqua Reports 37 (Berglund commemorative volume), University of Lund, 45-54

Jensen, J. B., Bennike, O., Witkowski, A., Lemke, W., Kuijpers, A. (1997): The Baltic Ice Lake in the southwestern Baltic: sequence-, chronoand biostratigraphy. - Boreas 26, 217-236.

Jensen, J. B., Bennike, O., Lemke, W., Kuijpers, A. (2005): The Storebælt gateway to the Baltic. - Geological Survey of Denmark and Greenland Bulletin 7, 45-48.

Kabailiene, M. (1999): Water level changes in SE Baltic based on diatom stratigraphy of Late Glacial and Holocene deposits. - Geologija 29: $15-29$.

Kiden, P., Denys, L., Johnston, P. (2002): Late Quaternary sea-level change and isostatic and tectonic land movements along the BelgianDutch North Sea coast: geological data and model results. - Journal of Quaternary Science 17, 535-546.

KJemperud, A. (1986): Late Weichselian and Holocene shoreline displacement in the Trondheimsfjord area, central Norway. - Boreas 15, 61-82.

Kliewe H., JANKe, W. (1982): Der holozäne Wasserspiegelanstieg der Ostsee im nordöstlichen Küstengebiet der DDR. - Petermanns Geographische Mitteilungen 126(2), 65-74.

KLIEWE, H., LANGE, E. (1971): Korrelationen zwischen pollenanalytischen und morphogenetisch-stratigraphischen Untersuchungen, dargestellt an Holozänablagerungen auf Rügen. - Petermanns Geographische Mitteilungen 115(1), 4-8.

KLUG, H. (1980): Der Anstieg des Ostseespiegels im deutschen Küstenraum seit dem Mittelatlantikum. - Eiszeitalter und Gegenwart 30, 237-252.

KöRBER-Grohne, U. (1964): Bestimmungsschlüssel für subfossile JuncusSamen und Gramineen-Früchte. - Hildesheim: Lax, 47 pp.

KösteR, R. (1961): Junge eustatische und tektonische Vorgänge im Küstenraum der südwestlichen Ostsee. - Meyniana 11, 23-81.

KolP, O. (1982): Eustatische und isostatische Veränderungen des südlichen Ostseeraumes im Holozän. - Petermanns Geographische Mitteilungen 123(3), 177-187.

Lambeck, K., Smither, C., Ekman, M. (1998): Tests for glacial rebound models of Fennoscandinavia based on instrumented sea- and lakelevel records. - Geophysical Journal International 135: 375-387.

LAMBECK, K. (1999): Shoreline displacements in southern - central Sweden and the evolution of the Baltic Sea since the last maximum glaciation. - Journal of the Geological Society, London 156, 465-486.

LAMPE, R. (2005a): Lateglacial and Holocene water-level variations along the NE German Baltic Sea coast: review and new results. - Quaternary International 133-134, 121-136.

LAMPE, R. (2005b): Reliefgenese und Faziesdifferenzierung am mesolithischen Fundplatz von Lietzow-Buddelin auf Rügen. - Bodendenkmalpflege in Mecklenburg-Vorpommern. Jahrbuch 2004, 52, 185-195.

LAmpe, R., Janke, W. (2004): The Holocene sea-level rise in the Southern Baltic as reflected in coastal peat sequences. - Polish Geological Institute Special Papers 11, 19-30.

Lampe, R., Endtmann, E., Janke, W., Meyer, H., Lübke, H., Harff, J., LEMKE, W. (2005): A new relative sea-level curve for the Wismar Bay, NE-German Baltic coast. - Meyniana 57, 5-35. 
Lange, E., JeschKe, L., KnApP, H.D. (1986): Ralswiek und Rügen. Landschaftsentwicklung und Siedlungsgeschichte der Ostseeinsel. Teil 1. Die Landschaftsgeschichte der Insel Rügen seit dem Spätglazial. Text und Beilagen. - Schriften zur Ur- und Frühgeschichte 38, 175 pp.

LANGE, W., MENKE, B. (1967): Beiträge zur frühpostglazialen erd- und vegetationsgeschichtlichen Entwicklung im Eidergebiet, insbesondere zur Flußgeschichte und zur Genese des sogenannten Basistorfes. Meyniana 17, 29-44.

LEMKE, W. (1998): Sedimentation und paläogeographische Entwicklung im westlichen Ostseeraum (Mecklenburger Bucht bis Arkonabecken) vom Ende der Weichselvereisung bis zur Litorinatransgression. - Unpublished habilitation thesis, Greifswald University, 186 pp.

Liebsch, G. (1997): Aufbereitung und Nutzung von Pegelmessungen für geodätische und geodynamische Zielstellungen. - Deutsche Geodätische Kommission bei der Bayerischen Akademie der Wissenschaften, Reihe C (485).

Ludwig, A. O. (2001a): Die neotektonische Ausgestaltung des südlichen Ostseeraumes. - Zeitschrift für geologische Wissenschaften 29(1/2), 149-167.

Ludwig, A. O. (2001b): Vertical movements since the beginning of Rupelian stage (map 1). - In: Garetsky, R. G., Ludwig, A. O., Schwab, G., Stackebrand, W. (2001): Neogeodynamics of the Baltic Sea depression and adjacent areas - Results of IGCP project 346. - Brandenburgische Geowissenschaftliche Beiträge 8(1).

LÜBKE, H. (2005): Vorbericht zu den Sondierungen submariner steinzeitlicher Fundstellen in den nördlichen Boddengewässern Rügens. Bodendenkmalpflege in Mecklenburg-Vorpommern, Jahrbuch 2004, 52, 211-220.

Mandelkow, E., Frenzel, P., Lampe, R., Kaute, P., Schindler, G. (2005) Paläontologische Untersuchungen von Sedimentprofilen der achäologischen Grabung Stralsund-Mischwasserspeicher. - Bodendenkmalpflege in Mecklenburg-Vorpommern, Jahrbuch 2004, 52, 263-281.

Ministerium FÜR BAU, LANDESENTWICKLUNG UND UMWELt (1994): Generalplan Küsten- und Hochwasserschutz Mecklenburg-Vorpommern. - Schwerin, $108 \mathrm{pp}$.

Montag, H. (1967): Bestimmung rezenter Niveauverschiebungen aus langjährigen Wasserstandsbeobachtungen der südlichen Ostseeküste. - Arbeiten aus dem Geodätischen Institut Postdam 15, 1-139.

MöRNER, N.-A. (1976): Eustatic changes during the last 8,000 years in view of radiocarbon calibration and new information from the Kattegat region and other northwestern European coastal areas. - Palaeogeography, Palaeoecology, Palaeoclimatology 19, 63-85.

MÖRNER, N.-A. (1980): The northwest European "sea-level laboratory" and regional Holocene eustasy. - Palaeogeography, Palaeoclimatology, Palaeoecology 29, 281-300.

Oberdorfer, E. (1994): Pflanzensoziologische Exkursionsflora. - Stuttgart: UTB für Wissenschaft, $1050 \mathrm{pp}$.

RössLER, D. (2006): Reconstruction of the Littorina Transgression in the Western Baltic Sea. - PhD thesis, Univ. Greifswald, 135 pp.

RosA, B. (1997): Bałtyk południowy - późny glacjał i pierwsza połowa Holocenu. - In: Florek, W. (Ed.): Geologia i geomorfologia pobrzeża i południowego Bałtyku. Wysza Szkoła Pedagogiczna w Słupsku, Słupsk, 13-27.
Rothmaler, W. (2002): Exkursionsflora von Deutschland. Band 4. Gefäßpflanzen - Kritischer Band. - Heidelberg: Spektrum Akad. Verl., 934 pp.

SaArse, L., Heinsalu, A., Karhu, J., Vassiljew, J., Veski, S. (2000) Holocene shoreline displacement and palaeogeography of the Kopu Peninsula, Hiiumaa Island, Estonia. - BALTICA 13, 15-23.

Schubert, R., Hilbig, W., Klotz, S. (1995): Bestimmungsbuch der Pflanzengesellschaften Mittel-und Nordostdeutschlands. - Jena: Fischer, 403 pp.

Schumacher W., BAYerl, K.-A. (1999): The shoreline displacement curve of Rügen Island (Southern Baltic Sea). - Quaternary International 56, 107-113.

Steffen, H., Kaufmann, G., Wu, P. (2006): Three-dimensional finite-element modeling of the glacial isostatic adjustment in Fennoscandia. Earth and Planetary Science Letters 250(1-2), 358-375.

Stigge, H.-J. (2003): Beobachtete Wasserstandsvariationen an der deutschen Ostseeküste im 19. und 20. Jahrhundert. - Küste 66, 79-102.

TAubER, F. (subm.): Search for palaeo landscapes in the south-western Baltic Sea with sidescan sonar. - Bericht der Römisch-Germanischen Kommission.

Terberger, T., Seiler, M. (2005): Flintschläger und Fischer-Neue interdisziplinäre Forschungen zu steinzeitlichen Siedlungsplätzen auf Rügen und dem angrenzenden Festland. - Bodendenkmalpflege in Mecklenburg-Vorpommern. Jahrbuch 2004, 52, 155-183.

Tomczak, A. (1995): Geological structure and Holocene evolution of the Polish coastal zone. - Journal of Coastal Research, Spec. Issue No. 22, 15-31.

Umbreit, C. (1939): Buddelin, ein mittelsteinzeitlicher Wohn- und Werkplatz bei Lietzow auf Rügen. - Mannus 31, 255-294.

Uścinowicz, S. (2006): A relative sea-level curve for the Polish Southern Baltic Sea. - Quaternary International 145-146, 86-105.

van De Plassche, O., Roep, T.B. (1989). Sea level changes in the Netherlands during the last 6500 years: basal peat vs. coastal barrier data. Late Quaternary Sea-Level Correlation and Applications (NATO ASI Series C, vol. 256), 41-56.

VEDDER, F. (2004): Morphologie und Taxonomie rezenter und subfossiler Characeen-Oogonien aus der Ostsee. - Rostocker Meeresbiologische Beiträge 13, 43-54.

Vink, A., Steffen, H., Reinhardt, L., Kaufmann, G. (2007): Holocene relative sea-level change, isostatic subsidence and the radial viscosity structure of the mantle of northwest Europe (Belgium, the Netherlands, Germany, southern North Sea). - Quaternary Science Reviews 26(25-28), 3249-3275

Winn, K., Averdieck, F.-R., Erlenkeuser, H., Werner F. (1986): Holocene sea level rise in the Western Baltic and the question of isostatic subsidence. - Meyniana 38, 61-80.

Winn, K., Erlenkeuser, H., Nordberg, K., Gustafsson, M. (1998): Paleohydrography of the Great Belt, Denmark, during the Littorina Transgression: the isotope signal. - Meyniana 50, 237-251. 